OPEN ACCESS

Edited by:

Malarvannan Govindan,

University of Antwerp, Belgium

Reviewed by:

Thomas McGrath,

University of Antwerp, Belgium

Thava Palanisami,

The University of Newcastle, Australia

K. Ramu,

National Centre for Coastal Research,

India

*Correspondence: Kurunthachalam Kannan Kurunthachalam.kannan@ nyulangone.org

Specialty section: This article was submitted to

Obesity,

a section of the journal

Frontiers in Endocrinology

Received: 14 June 2021

Accepted: 26 July 2021

Published: 18 August 2021

Citation:

Kannan K and Vimalkumar K (2021) A

Review of Human Exposure to

Microplastics and Insights Into

Microplastics as Obesogens.

Front. Endocrinol. 12:724989.

doi: 10.3389/fendo.2021.724989

\section{A Review of Human Exposure to Microplastics and Insights Into Microplastics as Obesogens}

\author{
Kurunthachalam Kannan ${ }^{*}$ and Krishnamoorthi Vimalkumar
}

Department of Pediatrics and Department of Environmental Medicine, New York University School of Medicine, New York, NY, United States

The ubiquitous exposure of humans to microplastics (MPs) through inhalation of particles in air and ingestion in dust, water, and diet is well established. Humans are estimated to ingest tens of thousands to millions of MP particles annually, or on the order of several milligrams daily. Available information suggests that inhalation of indoor air and ingestion of drinking water bottled in plastic are the major sources of MP exposure. Little is known on the occurrence of MPs in human diet. Evidence is accumulating that feeding bottles and medical devices can contribute to MP exposure in newborns and infants. Biomonitoring studies of human stool, fetus, and placenta provide direct evidence of MP exposure in infants and children. MPs $<20 \mu \mathrm{m}$ were reported to cross biological membranes. Although plastics were once perceived as inert materials, MP exposure in laboratory animals is linked to various forms of inflammation, immunological response, endocrine disruption, alteration of lipid and energy metabolism, and other disorders. Whereas exposure to MPs itself is a concern, MPs can also be sources of exposure to plastic additives and other toxicants. Exposure of human cell lines to MP additives such as phthalates, bisphenols, and organotins causes adverse effects through the activation of nuclear receptors, peroxisome proliferator-activated receptors (PPARs) $\alpha, \beta$, and $\gamma$, and retinoid $X$ receptor $(R X R)$, leading to oxidative stress, cytotoxicity, immunotoxicity, thyroid hormone disruption, and altered adipogenesis and energy production. The size, shape, chemical composition, surface charge, and hydrophobicity of MPs influence their toxicity. Maternal transfer of MPs to the developing fetus has been demonstrated in exposed laboratory animals and through the analysis of human placenta. In laboratory animal studies, maternal exposure to MPs altered energy and lipid metabolism in offspring and subsequent generations. Moreover, concomitant with the global increase in plastics production, the prevalence of overweight and obesity in human populations has increased over the past five decades, and there is evidence to support the hypothesis that MPs and their additives are potential obesogens. Even though MP exposures are ubiquitous and toxic effects from such exposures are a concern, systematic studies on this topic remain urgently needed.

Keywords: microplastics, adipogenesis, PPARs, phthalates, obesogens 


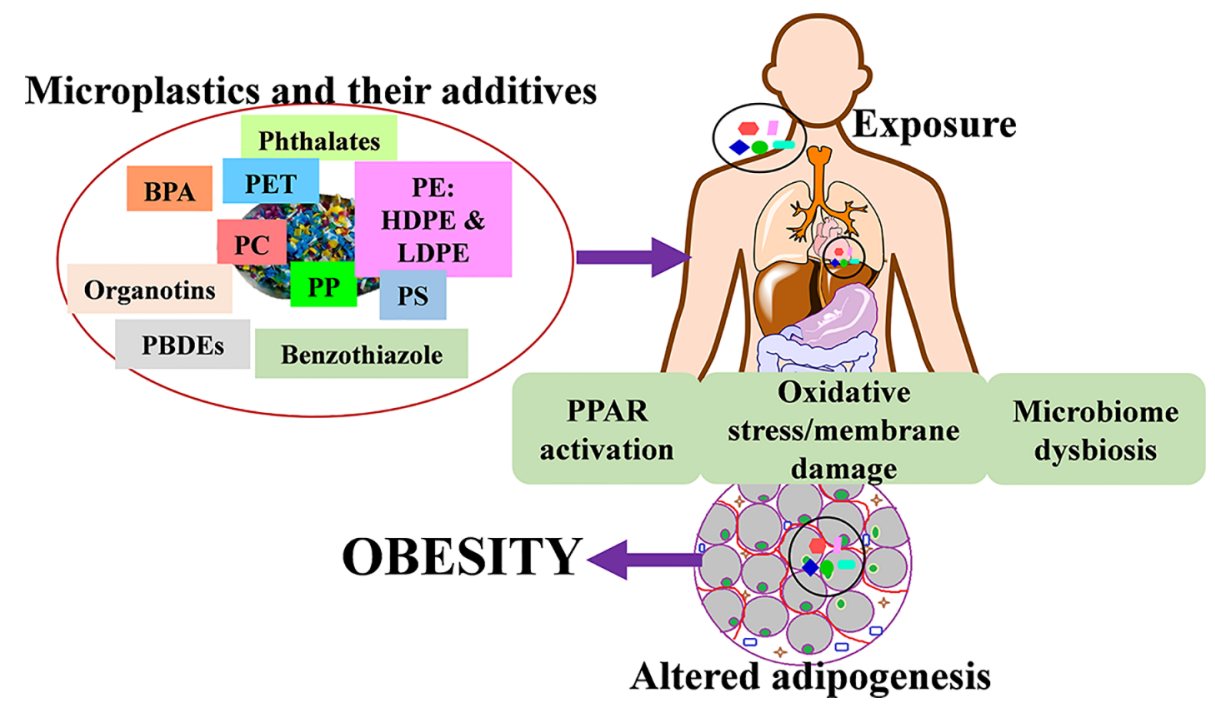

GRAPHICAL ABSTRACT

\section{INTRODUCTION}

Global plastic pollution is a significant environmental and public health concern (1-5). A total of approximately 8300 million metric tons of plastics were manufactured from 1950 to 2015 (6), and production rate has been increasing, reaching 368 million metric tons (annually) in 2019 (Figure 1). Plastics are resistant to chemical and biological degradation and therefore durable. Furthermore, their low density and expense coupled with corrosion resistance make them suitable for use in an enormous variety of consumer products. There are currently at least 45 different types of plastics in commercial use, including polypropylene (PP), polyethylene (PE), polyethylene terephthalate $(\mathrm{PET})$, polystyrene (PS), polyurethane (PU), polyvinyl chloride (PVC), and polycarbonate (PC) (7). According to Plastic Europe (2013) (www.plasticseurope.org/ application/files/7815/1689/9295/2013plastics_the_facts_ PubOct2013.pdf), of the $\sim 288$ million tons of plastics produced in 2012, 85 million tons ( 30\%) were PE, 54 million tons (19\%) were PP, and 31 million tons (11\%) were PVC. PE (as low- and

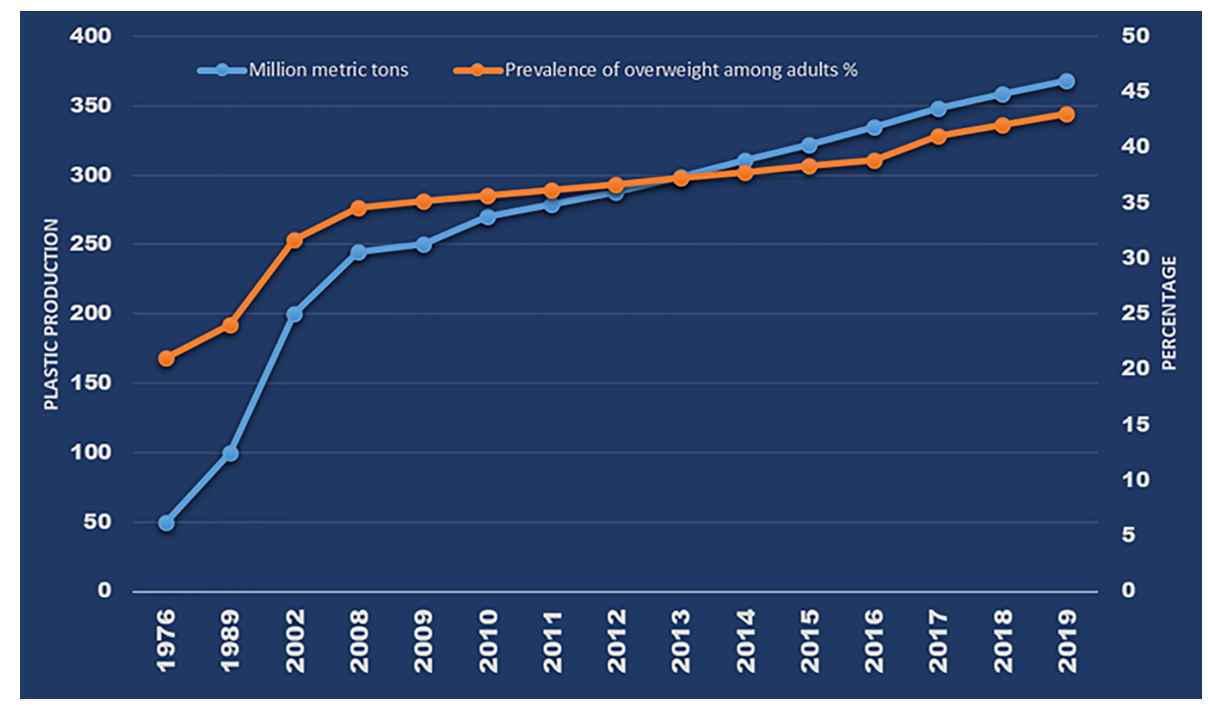

FIGURE 1 | Global annual plastic production and prevalence of overweight over the past 4 decades (Source: Plastics - The Facts 2020, page 16; WHO: https:// apps.who.int/gho/data/view.main.GLOBAL2461A?lang=e; Obesity data from: CDC: https://www.cdc.gov/nchs/products/databriefs/db360.htm). 
high-density material; LDPE/HDPE) is used in producing plastic films (35 million tons annually) that are finished as carrier bags, sandwich bags, food wraps and containers, straws, toys, mulch, irrigation pipes, packaging foam, cling wrap, and electrical cables, among other products. PP is the second most widely used thermoplastic worldwide, in applications ranging from plastic packaging, plastic parts for machinery and equipment, and medical devices to fibers and textiles. PVC is used in buildings (e.g., window shutters, water pipes, and upholstery), shampoo and cooking-oil bottles, insulation for electric cables, and cling films. PS is used in buildings and in moldable materials, especially for the production of disposable plates and cups, meat trays, egg cartons, carryout containers, and electronic goods. $\mathrm{PET}$, which is related to PE, is used in textile fibers for clothing manufacture (as polyester) and in containers for liquids (e.g., water, juice, and soft drink bottles) and foods (8). PET is an excellent replacement product for glass, and its demand is 14.5 million tons annually (Plastic Europe, 2008: https://www. plasticseurope.org/application/files/2815/1689/9283/ 2006compelling_fact_PubJan2008.pdf). Consumption rates of plastics vary between countries-according to Plastics Insight (https://www.plasticsinsight.com/world-per-capitaconsumption-pe-pp-pvc-resins-2014), per capita plastic consumption levels in the United States and India in 2014 were 95 and $8 \mathrm{~kg}$, respectively - but continue to increase on a global basis. Concurrent with the production and use of plastics, the generation of plastic waste has increased exponentially in the past 4 decades (6).

It is generally believed that large plastic polymers are inert and are not absorbed by the intestinal system (due to their size), and therefore are excreted un-metabolized. However, upon entering the environment and/or in biological systems, plastics break down into small particles through biotic and abiotic weathering and transformation processes, creating massive amounts of smaller plastic particles in the environment, including plastic particles of $<5 \mathrm{~mm}$ that are termed 'microplastics' (MPs) (9). An estimated 75,000-300,000 tons of MPs are released by plastics breakdown annually in the EU alone (10). As plastics continue to break down in the environment, the fraction of MPs in the total mass of plastic waste has been predicted to reach $13 \%$ by 2060 and will continue to increase (11). MPs are classified as primary or secondary based on their source of environmental release. Primary MPs are those deliberately manufactured at sizes $<5$ $\mathrm{mm}$ for use in applications such as microbeads in facial cleansers/ scrubs, shower gels, and scrubbing pads (dish washing), as well as microfibers from clothing (dish cloths and towels) (12-17). Secondary MPs are those generated from plastic polymers through normal weathering processes, including erosion, abrasion, corrosion, photo-oxidation (chemical), and biological transformation (18-21). MPs are also classified based on their physicochemical properties as microfibers from cloth (fleece, diapers, cigarette butts), fragments (larger particles from cutlery and lids), nurdles (plastic pellets), foams (cups, plates, food packaging containers), microbeads (plastics $<1 \mathrm{~mm}$ in diameter; used in toiletries, facial cleansers, exfoliating soap products and toothpaste), and nanoplastics (plastics 1-100 nm in diameter; potentially derived from disintegration of MPs) $(22,23)$.

MPs persist in the environment for hundreds to thousands of years. For example, plastic PET water bottles, disposable diapers, and PS foams have been estimated to have lifespans of 450,500, and $>5,000$ years in the environment, respectively (https://www. goecopure.com/lifespan-of-plastic.aspx). Not only is pollution by MPs themselves a significant environmental concern, but plastic particles also can release additives and other performanceenhancing chemicals that are incorporated into the polymers during production. These include inorganic fillers (to fortify the plastic), heat stabilizers (to impart heat resistance), plasticizers (to make plastic flexible and pliant), flame retardants (to provide ignition and fire resistance), UV stabilizers (to prevent degradation from sunlight/photo-oxidation), colorants (to provide opacity and matte finish), and luster additives (to enhance appearance). Owing to their high costs, these additives are typically added in relatively small concentrations (8, 24-26), but they may have potent biological effects. Additives including bisphenols, phthalates, benzothiazoles, organotins, and polybrominated diphenyl ethers (PBDEs) leach out of plastics during usage and/or after disposal (8, 27-32). Aquatic and terrestrial pollution by plastics additives has been extensively documented. Furthermore, MPs can act as vectors for various other contaminants, as they sequester organic and inorganic pollutants from the surrounding environment (33).

Several studies have reported the ubiquitous occurrence of MPs in various environmental matrices, including surface water, sediment, wastewater, Arctic and Antarctic sea ice, indoor and outdoor air, bottled water, and select food products $(7,34-44)$. Whereas studies of MP pollution in the aquatic environment, especially the oceanic environment, have received considerable attention for over a decade, effects of MPs on human health have attracted notice quite recently, following the detection of MPs in seafood, honey, milk, beer, table salt, drinking water, and air (45). Furthermore, the identification of MPs in human placenta raised serious concern about exposure in utero (46). A meta-analysis of existing data on the concentrations of MPs in various sources of human exposure suggested a mean ingestion dose in the range of 0.10-5 g/week (47). Zhang et al. (48) assessed the mass of PET and PC MPs recovered from the feces of dogs and cats, which were used as surrogates for biomonitoring of MPs in humans, and found an excretion rate of 0.03-677 mg MPs/week. These exposure dose estimates are several orders of magnitude higher than those for other toxicants, such as phthalates, bisphenols, and toxic metals. Thus, there is clear evidence of substantial human exposure to MPs.

Although plastics were thought of as inert materials, several studies in recent years have described health risks from exposure to MPs in humans. Among the various toxic effects reported in laboratory animals from exposure to MPs and plastic additives, the disruption of adipogenesis and lipid metabolism through the activation of peroxisome proliferator-activated receptors (PPARs) suggests that MP exposure may be linked to the increasing prevalence of obesity globally. The increase in global 
plastics production over the past 50 years is in line with the rate of increase in overweight and obesity in human populations (Figure 1). Thus, there is an immediate need to assess the sources, pathways, and potential health effects of MPs in humans, with a focus on obesogenic mechanisms, among others. In this review, we summarize available information on the sources and pathways of human exposure to MPs and on their toxic effects, especially those related to obesogenic mechanisms of MP toxicity.

\section{SOURCES OF HUMAN EXPOSURE TO MICROPLASTICS}

A major difficulty in determining the risks of MPs to human health is the lack of accurate information on exposure doses, which is primarily due to the fact that methods for quantitative determination of MPs in air, water, food, and cosmetics are still evolving. A complicating factor is that the available spectroscopy-based methods report MPs (items, fibers, or particles) in terms of number, size, and shape, whereas in exposure science, doses are most often reported in mass. Reported concentrations of MPs in various sources of human exposure (air, indoor dust, drinking water, beverages, honey, salt, sugar, and other dietary sources) from a number of recent papers are compiled in Table 1. Contaminated food and water were thought to be major sources of MP exposure. One study reported a per capita intake of MPs through ingestion of food, water, and dust and inhalation of air of 74,000-121,000 items annually (45). Another study estimated an annual per capita MP intake of 39,000-52,000 items, including 37-1000 from sea salt, 4000 from tap water, and 11,000 from shellfish (42). A probabilistic lifetime exposure model predicted a MP intake rate of $184 \mathrm{ng} / \mathrm{capita} / \mathrm{d}$ for children and $583 \mathrm{ng} /$ capita/d for adults, through nine different exposure sources (109). Mass (or weight)-based estimates of annual MP ingestion were reported to be 15-287 g/person (47). Through analysis of the feces of cats and dogs, as surrogates for humans, Zhang et al. (48) reported an MP intake estimate of 0.03-677 mg/week for pet animals. Overall, through the analysis of pet feces, daily exposure doses on the order of several tens of milligrams were reported. The contribution of various sources to the total MP exposure dose is delineated below.

\section{Indoor/Outdoor Air and Dust}

Although diet was previously thought to be the major pathway of human exposure to MPs, recent studies on airborne MPs provide evidence that inhaled indoor air may be the dominant source $(45,110)$. With their small size and low density, MPs can be suspended and transported by air, and airborne MPs are directly inhaled by humans. At an average reported air concentration of $9.8 \mathrm{MPs} / \mathrm{m}^{3}$ (45) and an inhalation rate of $15 \mathrm{~m}^{3} /$ day, annual inhalation exposure averaged 53,700 particles per person in one study. Distribution of MPs in atmospheric fallout or road dust in Paris (France), Tehran (Iran), Dongguan (China), Kusatsu (Japan), Da Nang (Vietnam), and Kathmandu (Nepal) has been documented $(54,111,112)$.
The reported units for MPs in air vary depending on the sampling method. A vast majority of studies measure concentrations in atmospheric fallout or deposition in the units of number of fibers, fragments, particles, or items per $\mathrm{m}^{2}$ (for fallout) or per $\mathrm{m}^{3}$ (for air) per day (Table 1). The reported amounts of airborne (deposition/flux) MPs in cities ranged from 2 to 925 particles $/ \mathrm{m}^{2} /$ day, and those in road dust ranged from 3 to 60 items per gram or 0.4 to 33.4 items per $\mathrm{m}^{2}$ (110). One study reported that the deposition rate of MPs in central London (England) varied between 575 and 1008 particles $/ \mathrm{m}^{2} /$ day (113). Much higher deposition rates, of up to $11,130 \mathrm{MPs} / \mathrm{m}^{2} /$ day, were reported in an indoor environment in Paris (France) (1). The study from Paris reported the occurrence of 0.3-15 (mean: 0.9) and $0.4-56.5$ (mean: 5.4 ) particles $/ \mathrm{m}^{3}$ in outdoor and indoor air, respectively (1), with concentrations of MPs in indoor air averaging approximately 5-10 times higher than those in outdoor air. Furthermore, the flux of MPs in urban air was approximately two-fold higher than that in suburban air in France (1), and lower atmospheric levels of MPs were reported in dry seasons than in rainy seasons (56). A study from Denmark showed that the most common types of MPs found in indoor air were PET (59-92\%), PE (5-28\%), PP (0.4-10\%), and nylon (0-13\%) (43). A study from China identified PET and acrylic fibers as the major airborne MPs in indoor air (59).

The major sources of MPs in indoor and outdoor air were synthetic textiles, degradation of plastics, building materials, waste incineration, and landfills $(1,56)$. Greater concentrations of MPs found in indoor than in outdoor air were attributed to release from textiles. Indoor air and dust are major contributors to human MP exposure. A study measuring the masses of PET and PC MPs in indoor dust from 12 countries reported the ubiquitous occurrence of PET-based MPs at concentrations of 38-120,000 $\mu \mathrm{g} / \mathrm{g}$ (median: $5900 \mu \mathrm{g} / \mathrm{g}$ ) and PC-based MPs at $<0.11-1700 \mu \mathrm{g} / \mathrm{g}$ (median: 8.8 $\mu \mathrm{g} / \mathrm{g}$ ) (48). Among various classes of micropollutants measured, PET was the most abundant chemical found in indoor dust thus far (Figure 2) (48). Geometric mean exposure doses to MPs through ingestion of indoor dust in adults and children were reported to be on the order of thousands of ng/kg-bw/day, with the highest value $(150,000 \mathrm{ng} / \mathrm{kg}$-bw) reported for PET exposure in infants (48). This corresponds to an estimated $\sim 10 \mathrm{mg} /$ day for a person weighing $70 \mathrm{~kg}$. This exposure dose is for PET MP alone, although it may reflect higher end of an exposure dose for that MP, based on the median concentration measured in indoor dust [see Zhang et al. (48) for details]. A few exposure models showed human inhalation doses of MPs in the range of 6.5-8.97 $\mu \mathrm{g} / \mathrm{kg}-\mathrm{bw} /$ day, with those in infants and toddlers being 3-50 times higher than those in adults $(48,110)$. Prata et al. (42) estimated average per capita inhalation exposure to MPs ranging between 26 and 130 particles per day. Another study showed that the inhaled amount of airborne MPs reached 272 particles per day (43). In general, a rough estimate of human inhalation and dust ingestion exposure to MPs is on the order of a few milligrams per day. However, inhalation doses of MPs can vary depending on the type of textiles in use and other indoor environmental factors (such as ventilation), and further studies are needed in this area (114). 
TABLE 1 | Reported concentrations of microplastics in air, dust, drinking water, sea food, food, beverages and human samples.

\begin{tabular}{|c|c|c|c|c|c|}
\hline Sample type & Location & Polymer type & Size & Concentration & Reference \\
\hline \multicolumn{6}{|l|}{ Air } \\
\hline \multirow[t]{3}{*}{ Indoor } & Aarhus, Denmark & Polyester, PE, nylon & 0.004-0.398 mm & 1.7-16.2 particles $/ \mathrm{m}^{3}$ & $(43)$ \\
\hline & Edinburgh, UK & PET, PU & $<5 \mathrm{~mm}$ & 1666-1671 particles $/ \mathrm{m}^{2 / d}$ & (49) \\
\hline & Paris, France & Not reported & $0.005-0.6 \mathrm{~mm}$ & $1586-11,130$ particles $/ \mathrm{m}^{2 /} \mathrm{d}$ & $(50)$ \\
\hline \multirow[t]{8}{*}{ Outdoor } & USA & $\begin{array}{l}\text { Cotton, polyster, nylon, polyolefin, } \\
\text { PTFE, PE }\end{array}$ & $0.004-3 \mathrm{~mm}$ & 132 particles $/ \mathrm{m}^{2 / \mathrm{d}}$ & $(51)$ \\
\hline & Asaluyeh county, Iran & Not reported & $0.002-0.1 \mathrm{~mm}$ & 72 items $/ \mathrm{m}^{3}$ & $(12)$ \\
\hline & Hamburg, Germany & PET, ethylvinyl acetate copolymers & $<0.063->0.3 \mathrm{~mm}$ & $136.5-512$ particles $/ \mathrm{m}^{2 /} \mathrm{d}$ & $(52)$ \\
\hline & Pyrenees mountains, France & PS, PE, PP, PVC, PET & $<0.025-2.6 \mathrm{~mm}$ & 366 particles $/ \mathrm{m}^{2 /} \mathrm{d}$ & (53) \\
\hline & Dongguan, China & PE, PP, PS, cellulose & $<0.2-4.2 \mathrm{~mm}$ & $175-313$ particles $/ \mathrm{m}^{2 /} \mathrm{d}$ & $(54)$ \\
\hline & Yantai, China & PS, PE, PP, PVC, PET & $0.005-1 \mathrm{~mm}$ & 0-602 particles $/ \mathrm{m}^{2 / d}$ & (55) \\
\hline & Paris, France & Not reported & $0.005-0.6 \mathrm{~mm}$ & 2-355 particles $/ \mathrm{m}^{2 / d}$ & $(56)$ \\
\hline & Bushehr port, Iran & PET, PE, nylon, PS, PP & $<2.5 \mu \mathrm{m}$ & 5.2 items $/ \mathrm{m}^{3}$ & $(57)$ \\
\hline \multicolumn{6}{|c|}{ Dust particles } \\
\hline \multirow[t]{5}{*}{ Indoor } & Several countries & PET & $<2 \mathrm{~mm}$ & $38-120,000 \mu \mathrm{g} / \mathrm{g}$ & $(58)$ \\
\hline & Shanghai, China & PS, polyamide, PP & 50-2000 $\mu \mathrm{m}$ & $4.4 \times 10^{3} \mathrm{MPs} / \mathrm{m}^{2 /} \mathrm{d}$ (mean) & (59) \\
\hline & Surabaya, Indonesia & & $3000-3500 \mu \mathrm{m}$ & 212 particles (mean) & $(60)$ \\
\hline & Tiajin, China & PET & $50 \mu \mathrm{m}-2 \mathrm{~mm}$ & $1550-120,000 \mathrm{mg} / \mathrm{kg}$ & $(61)$ \\
\hline & & PC & $50 \mu \mathrm{m}-2 \mathrm{~mm}$ & $4.6 \mathrm{mg} / \mathrm{kg}$ & \\
\hline \multirow[t]{2}{*}{ Outdoor } & Tiajin, China & PET & $50 \mu \mathrm{m}-2 \mathrm{~mm}$ & $212-9020$ mg/kg & \\
\hline & & PC & $50 \mu \mathrm{m}-2 \mathrm{~mm}$ & $2 \mathrm{mg} / \mathrm{kg}$ & \\
\hline \multicolumn{6}{|c|}{ Drinking water } \\
\hline Packed water & Bangkok, Thailand & PET, PE, PP, polyamide, PVC & $\geq 50 \mu \mathrm{m}$ & $140 \mathrm{MPs} / \mathrm{L}$ & $(62)$ \\
\hline bottle & Catania, Italy & PET & $0.5-10 \mu \mathrm{m}$ & $657 \pm 633 \mu \mathrm{g} / \mathrm{L}$ & (63) \\
\hline Glass bottles & Erlangen, Germany & PE & $>5 \mu \mathrm{m}$ & $6292 \pm 10521$ particles $/ L$ & $(64)$ \\
\hline Single use & & & & $2649 \pm 2857$ particle/L & \\
\hline \multicolumn{6}{|l|}{ PET bottles } \\
\hline Reusable & & & & $195047 \pm 330810$ pigmented & \\
\hline PETbottles & & & & particle/L & \\
\hline $\begin{array}{l}\text { Reusable PET } \\
\text { bottles }\end{array}$ & & & & $\begin{array}{l}23594 \pm 25518 \text { pigmented } \\
\text { particle/L }\end{array}$ & \\
\hline Bottled water & NewYork, USA & PP, nylon & $>100 \mu \mathrm{m}$ & $0-14 \mathrm{MPs} / \mathrm{L}$ & $(65)$ \\
\hline $\begin{array}{l}\text { Packed } \\
\text { mineral water }\end{array}$ & Germany & PET, PE, PP, polyamide & $50-500 \mu m$ & $28-241 \mathrm{MPs} / \mathrm{L}$ & $(66)$ \\
\hline Mineral water & & PET & & 1 (only one found) MPs/L & $(67)$ \\
\hline $\begin{array}{l}\text { Drinking water } \\
\text { fountain }\end{array}$ & Metro-station, Mexico city & poly-trimethylene terephthalate & $0.1-5 \mathrm{~mm}$ & $5 \pm 2$ to $91 \pm 14 \mathrm{MPs} / \mathrm{L}$ & $(68)$ \\
\hline \multirow[t]{5}{*}{ Tap water } & Qingdao, China & $\begin{array}{l}\text { PE, PS, PET, rayon, polyester, } \\
\text { polyacrylic, polymethylpentene, } \\
\text { polyimide }\end{array}$ & 10 to $5000 \mu \mathrm{m}$ & $0.3-1.6 \mathrm{MPs} / \mathrm{L}$ & (69) \\
\hline & North-western Germany & $\begin{array}{l}\text { PS, PVC, polyamide, epoxy resin, } \\
\text { PE }\end{array}$ & $>20 \mu \mathrm{m}$ & 0-0.0007 MPs/L & $(70)$ \\
\hline & Minneapolis, Minnesota, USA & Synthetic polymers & $0.1-5 \mathrm{~mm}$ & 5.45 particles/L & (71) \\
\hline & Czech Republic & PET, PP, PE & $<10 \mu \mathrm{m}$ & 469.6 MPs/L (mean) & $(72)$ \\
\hline & Different parts of China & PE, PP, PET & 3 to $4453 \mu \mathrm{m}$ & 0 - $1247 \mathrm{MPs} / \mathrm{L}$ & $(73)$ \\
\hline \multicolumn{6}{|l|}{ Diet } \\
\hline Sea salt & Bulgaria & $\mathrm{PP}$ & $100-5000 \mu \mathrm{m}$ & 12 items/kg & $(74)$ \\
\hline Rock salt & & $P P, P E$ & & 8 items/kg & \\
\hline Sea salt & China & & $45-4300 \mu \mathrm{m}$ & $550-680$ items $/ \mathrm{kg}$ & \\
\hline Rock salt & & & & 43-364 items/kg & \\
\hline Lake salt & & & & 7-204 items/kg & \\
\hline Sea salt & France & PS & $160-980 \mu \mathrm{m}$ & 0-2 items/kg & \\
\hline Rock salt & Germany & & $100 \mu \mathrm{m}$ & 2 items/kg & \\
\hline Rock salt & Hungary & Low density PE & $100-4000 \mu \mathrm{m}$ & 12 items/kg & \\
\hline Sea salt & India & & $1000-5000 \mu \mathrm{m}$ & (30-370 items/kg & \\
\hline Sea salt & Indonesia & $\mathrm{PP}$ & & 1400 items $/ \mathrm{kg}$ & \\
\hline Sea salt & Italy & & $1000-5000 \mu \mathrm{m}$ & 4-30 items/g & \\
\hline Rock salt & & & & 80 items/kg & \\
\hline Sea salt & Korea & $P E$ & $100-3000 \mu \mathrm{m}$ & $100-230$ items/kg & \\
\hline Rock salt & Philippines & & $100-5000 \mu \mathrm{m}$ & 120 items/kg & \\
\hline Sea salt & Senegal & & $100-3000 \mu \mathrm{m}$ & 48 items/kg & \\
\hline Rock salt & & & & 800 items/kg & \\
\hline Sea salt & Thailand & & $100-5000 \mu \mathrm{m}$ & $70-400$ items $/ \mathrm{kg}$ & \\
\hline
\end{tabular}


TABLE 1 | Continued

\begin{tabular}{|c|c|c|c|c|c|}
\hline Sample type & Location & Polymer type & Size & Concentration & Reference \\
\hline Sea Salt & USA & & & $50-800$ items $/ \mathrm{kg}$ & \\
\hline Rock salt & & & & $113-367$ items $/ \mathrm{kg}$ & \\
\hline Sea salt & UK & & $100-2000 \mu \mathrm{m}$ & 140 items $/ \mathrm{kg}$ & \\
\hline Sea salt & Vietnam & & $100-5000 \mu \mathrm{m}$ & $76-88$ items $/ \mathrm{kg}$ & \\
\hline Beer & Germany & & Not specified & $\begin{array}{l}\text { 2-79 fibers/L } \\
\text { 12-109 fragments/L } \\
\text { 2-66 granules/L }\end{array}$ & $(75)$ \\
\hline & Duluth, Minnesota, USA & & $100-5000 \mu \mathrm{m}$ & 0-14.3 particles/L & $(71)$ \\
\hline Honey & Germany, France, Italy, Spain and Mexico & & $10-20 \mu \mathrm{m}$ & $\begin{array}{l}166 \pm 147 \text { fibers } / k g \\
9 \pm 9 \text { fragments } / k g\end{array}$ & $(76)$ \\
\hline Sugar & & & & $\begin{array}{l}217 \pm 123 \text { fibers } / \mathrm{kg} \\
32 \pm 7 \text { fragments } / \mathrm{kg}\end{array}$ & \\
\hline Honey & Switzerland & & $500 \mu \mathrm{m}$ & $\begin{array}{l}1760-8680 / \mathrm{kg} \text { (black } \\
\text { particles) } \\
132-728 / \mathrm{kg} \text { (white fibers) } \\
60-172 / \mathrm{kg} \text { (white particles) } \\
32-108 / \mathrm{kg} \text { (coloured fibers) }\end{array}$ & $(77)$ \\
\hline $\begin{array}{l}\text { Canned } \\
\text { sardines and } \\
\text { sprats }\end{array}$ & Australia and Malaysia & & $190-3800 \mu \mathrm{m}$ & 20 (mean) items/g & $(78)$ \\
\hline Seaweed nori & China & & $100-500 \mu m$ & $0.9-3.0$ items $/ g$ & (79) \\
\hline Tea bags & $\begin{array}{l}\text { Canada (billion microplastics and } 3.1 \\
\text { billion nanoplastics single cup of the } \\
\text { beverage) }\end{array}$ & fibers & $25 \mu \mathrm{m}$ & 11.6 items/g & (80) \\
\hline \multicolumn{6}{|c|}{ Oyster, bivalves and mussels (Seafood) } \\
\hline Location & Species name & Tissue & Size & Concentration & Reference \\
\hline California, USA & Crassostrea gigas & Soft tissue & $>500 \mu \mathrm{m}$ & 0.6 particles $/ g$ & (81) \\
\hline $\begin{array}{l}\text { Brittany, } \\
\text { France }\end{array}$ & Crassostrea gigas & & $5-25 \mu \mathrm{m}$ & 0.47 particles $/ g$ & (82) \\
\hline Shanghai, & Meretrix lusoria & & $5-5000 \mu \mathrm{m}$ & 9.22 paticles/individual & (83) \\
\hline China & $\begin{array}{l}\text { Mytilus galloprovincialis } \\
\text { Patinopecten yessoensis }\end{array}$ & & $\begin{array}{l}5-5000 \mu \mathrm{m} \\
5-5000 \mu \mathrm{m}\end{array}$ & $\begin{array}{l}4.33 \pm 2.62 \text { particles/individual } \\
57.2 \pm 17.3 \text { particles/individual }\end{array}$ & \\
\hline Italy & Mytilus galloprovincialis & Hepatopancreas and gills & $760-6000 \mu \mathrm{m}$ & 6.2-7.2 particles/g & (84) \\
\hline Scottish coast & $\begin{array}{l}\text { Mytilus spp. } \\
\text { Modiolus modiolus }\end{array}$ & Soft tissue & $\begin{array}{l}200->2000 \mu \mathrm{m} \\
200->2000 \mu \mathrm{m}\end{array}$ & $\begin{array}{l}3.2 \pm 0.52 \text { paticles/individual } \\
3.5 \pm 1.29 \text { paticles/individual }\end{array}$ & (49) \\
\hline $\begin{array}{l}\text { Musa estuary, } \\
\text { Persian Gulf }\end{array}$ & Penaeus semisulcatus & Muscle, skin & $<100->1000 \mu \mathrm{m}$ & 7.8 particles/individual & (85) \\
\hline $\begin{array}{l}\text { Persian Gulf, } \\
\text { Iran }\end{array}$ & Pinctala radiata & Soft tissue & $10-5000 \mu \mathrm{m}$ & 11 particles/individual & (86) \\
\hline $\begin{array}{l}\text { East China } \\
\text { Sea }\end{array}$ & Mytilus spp. & & $1000-5000 \mu m$ & $3.69 \pm 9.16$ items $/ g$ & $(87)$ \\
\hline UK coast & Mytilus edulis & & $500 \mu \mathrm{m}$ & $\begin{array}{l}0.7 \text { to } 2.9 \text { items } / g \\
1.1 \text { to } 6.4 \text { items/individual }\end{array}$ & (88) \\
\hline South Korea & $\begin{array}{l}\text { Crassostrea gigas, Mytilus edulis, Tapes } \\
\text { philippinarum, Patinopecten yessoensis }\end{array}$ & & $300 \mu \mathrm{m}$ & $\begin{array}{l}\text { Mean: } 0.15 \pm 0.20 \mathrm{n} / \mathrm{g} \text { species } \\
\text { and } 0.97 \pm 0.74 \mathrm{n} / \mathrm{individual}\end{array}$ & (89) \\
\hline Belgium coast & Mytilus edulis & & $200-1500 \mu \mathrm{m}$ & 2.6 to 5.1 fibers $/ 10 \mathrm{~g}$ & $(90)$ \\
\hline Fuzhou, China & Bivalve & & $320-1600 \mu \mathrm{m}$ & $\begin{array}{l}0.11-0.12 \text { items/g and 0.59- } \\
1.44 \text { items/individual }\end{array}$ & (91) \\
\hline Xiamen, China & Bivalve & & $100-4000 \mu \mathrm{m}$ & $\begin{array}{l}0.28-0.30 \text { items/g and } 1.26- \\
1.56 \text { items/individual }\end{array}$ & \\
\hline \multicolumn{6}{|l|}{ Fishes } \\
\hline Saudi Arabian & Acanthurus gahhm & Gastrointestinal tract & $2700 \mu \mathrm{m}$ & 10 per g (mean) & (92) \\
\hline Red sea coast & $\begin{array}{l}\text { Epinephelus areolatus } \\
\text { Epinephelus chlorostigma }\end{array}$ & & $\begin{array}{l}1800 \mu \mathrm{m} \\
1900 \mu \mathrm{m}\end{array}$ & $\begin{array}{l}10 \text { per individual (mean) } \\
3 \text { per individual (mean) }\end{array}$ & \\
\hline $\begin{array}{l}\text { Northeast } \\
\text { Persian Gulf }\end{array}$ & Alepes djedaba & muscle & $<100-5000 \mu \mathrm{m}$ & 20 per individual (mean) & (93) \\
\hline $\begin{array}{l}\text { Musa estuary, } \\
\text { Persian Gulf }\end{array}$ & Cynoglossus abbreviatus & Muscle, gut, gills, liver, skin & $<100->1000 \mu \mathrm{m}$ & 11 per individual (mean) & (85) \\
\hline $\begin{array}{l}\text { Mondego } \\
\text { estuary, } \\
\text { Portugal }\end{array}$ & $\begin{array}{l}\text { Dicentrarchus labrax } \\
\text { Diplodus vulgaris }\end{array}$ & Gastrointestinal tract & $\leq 1000-5000 \mu \mathrm{m}$ & $\begin{array}{l}40 \text { per individual (mean) } \\
40 \text { per individual (mean) }\end{array}$ & (94) \\
\hline Mediterranean & Engraulis encrasicolus & Liver & $124-438 \mu \mathrm{m}$ & 10 per individual (mean) & (95) \\
\hline Sea, Spain & & Gastrointestinal tract & Not specified & 105 per individual (mean) & (96) \\
\hline
\end{tabular}


TABLE 1 | Continued

\begin{tabular}{|c|c|c|c|c|c|}
\hline Sample type & Location & Polymer type & Size & Concentration & Reference \\
\hline $\begin{array}{l}\text { Tokyo Bay, } \\
\text { Japan }\end{array}$ & Engraulis japonicus & & $10-500 \mu m$ & 64 per individual (mean) & $(97)$ \\
\hline $\begin{array}{l}\text { Goiana } \\
\text { estuary, Brazil }\end{array}$ & Cynoscion acoupa & Gut & $5000 \mu \mathrm{m}$ & 552 per individual (mean) & (98) \\
\hline $\begin{array}{l}\text { Spanish } \\
\text { Atlantic }\end{array}$ & Merluccius merluccius & Stomach & $380-3100 \mu m$ & 12 per individual & (99) \\
\hline Indian coast & Sardinella longiceps & Gut & $500-3000 \mu m$ & 10 per individual & $(100)$ \\
\hline East China & Wild fish species & Gill & $24-268 \mu \mathrm{m}$ & $0.77 \pm 1.25$ items/individual & $(101)$ \\
\hline Sea & Crustacean spp. & Gastrointestinal & $32-4092 \mu \mathrm{m}$ & $0.52 \pm 0.90$ items/individual & \\
\hline $\begin{array}{l}\text { South China } \\
\text { Sea }\end{array}$ & Deep sea fishes (13 species) & Stomach and intestine & $40-200 \mu m$ & $\begin{array}{l}1.96 \pm 1.12 \text { items/individual } \\
\text { and } 1.77 \pm 0.73 \text { items/ } \\
\text { individual }\end{array}$ & $(102)$ \\
\hline Fuzhou, China & Wild fishes & Gastrointestinal & $440-11000 \mu m$ & $\begin{array}{l}0.60-0.65 \text { items/g and 1.69- } \\
2.29 \text { items/individual }\end{array}$ & $(91)$ \\
\hline Xiamen, China & & & $450-7200 \mu m$ & $\begin{array}{l}0.49-1.26 \text { items/g and } 2.39 \text { - } \\
4.71 \text { items/individual }\end{array}$ & $(90)$ \\
\hline $\begin{array}{l}\text { Southern } \\
\text { Caspian Sea }\end{array}$ & Rutilus frisii kutum & Stomach & $<500 \mu \mathrm{m}$ & 11.4 itmes/fish & $(103)$ \\
\hline $\begin{array}{l}\text { Northern } \\
\text { lonian Sea, } \\
\text { Greece }\end{array}$ & $\begin{array}{l}\text { Mytilus galloprovincialis, Sardina } \\
\text { pilchardus, Pagellus erythrinus, Mullus } \\
\text { barbatus }\end{array}$ & Gills, stomach, intestines & $0.5-0.1 \mathrm{~mm}$ & $\begin{array}{l}\text { 1.7-2 items/individual and } \\
1.5-1.9 \text { items/individual }\end{array}$ & $(104)$ \\
\hline $\begin{array}{l}\text { Bay of Bengal, } \\
\text { India }\end{array}$ & Marine fish (10 species) & Gastrointestinal & $<500 \mu \mathrm{m}$ & $2.2 \pm 0.89$ items/individual & $(105)$ \\
\hline $\begin{array}{l}\text { Southern } \\
\text { Caspian Sea }\end{array}$ & Chelon Aurata, Rutilus kutum & Gut & 1.94 mm (mean) & 2.29 MPs/fish & $(106)$ \\
\hline \multicolumn{6}{|c|}{ Human specimens } \\
\hline Sample type & Location & Polymer type & Size & Concentration & Reference \\
\hline $\begin{array}{l}\text { Human } \\
\text { placenta }\end{array}$ & Rome, Italy & PP and others & $5-10 \mu \mathrm{m}$ & 12 fragments in 4 placentas & $(46)$ \\
\hline Human feces & Vienna, Austria & PP, PET & 50 to $500 \mu \mathrm{m}$ & $20 \mathrm{MPs}$ per $10 \mathrm{~g}$ of stool & $(107)$ \\
\hline Lung tissue & Sao Paulo, Brazil & $\begin{array}{l}\text { PP, PE, PVC, cellulose acetate, } \\
\text { polyamide, PS, PU }\end{array}$ & $\begin{array}{l}<5.5 \mu \mathrm{m} \text { particles } \\
\text { and } 8.1-16.8 \mu \mathrm{m} \\
\text { fibers }\end{array}$ & $\begin{array}{l}\text { Mean: } 0.59 \mathrm{MP} / \mathrm{g}(470 \\
\text { particles per lung) }\end{array}$ & $(108)$ \\
\hline Pet feces & Albany, New York, USA & $\begin{array}{l}\text { PET } \\
\text { PC }\end{array}$ & $\begin{array}{l}<2.4 \mathrm{~mm} \\
<2.4 \mathrm{~mm}\end{array}$ & $\begin{array}{l}\text { Cat: }<2,300-340,000 \mathrm{ng} / \mathrm{g} \mathrm{dw} \\
\text { Dog: } 7,700-190,000 \mathrm{ng} / \mathrm{g} \mathrm{dw} \\
\text { Cat: }<32 \text { to } 13,000 \mathrm{ng} / \mathrm{g} \mathrm{dw} \\
\text { Dog: }<32-26,000 \mathrm{ng} / \mathrm{g} \mathrm{dw}\end{array}$ & $(48)$ \\
\hline
\end{tabular}

PE, polyethylene; PET, polyethylene terephthalate; PC, polycarbonate; PP, polypropylene; PU, polyurethane; PTFE, polytetrafluroethylene; PS, polystyrene; PVC, polyvinylchloride.

A human biomonitoring study reported the presence of plastic fibers in pulmonary tissue (115), suggesting that airborne MPs can deposit or accumulate in lungs. Fibrous particles of a few tens of microns in size are reported to deposit in lungs (116). Although alveolar macrophages engulf MPs, particles $15-20 \mu \mathrm{m}$ in size are toxic (to macrophages) and eventually enter the circulatory and lymphatic systems (117). Other studies have reported that MPs can induce inflammatory response, cytotoxicity, and genotoxicity in lung tissue (118); that occupational exposure to airborne MPs among workers in synthetics mills is associated with respiratory illnesses (42); and that long-term MP exposure leads to lung diseases, including asthma and pneumoconiosis $(42,119)$. Although a few studies have described the significance of indoor air and dust as the major sources of MP exposure in humans, their relative contributions to cumulative exposure are not known. Further research is needed to quantitatively assess exposure doses to various types and sizes of MPs through air inhalation and dust ingestion, along with the concomitant health effects.
Biomonitoring studies of MPs in lung biopsies will increase our understanding of the effects of MPs on respiratory health. Because no standard method exists for determining MP levels in air and dust, efforts are also needed to harmonize the analytical methods as a first step in this direction.

\section{Drinking Water and Packaged Beverages}

MPs have been widely found in freshwater resources, and therefore it is considered that drinking water derived from such sources contain MPs. One study documented lower concentrations of MPs in groundwater compared to tap and bottled water, suggesting that MPs originate from water distribution and/or bottling processes (120). Drinking water treatment can remove up to $88 \%$ of MPs through coagulation-flocculation-sedimentation (72). Schymanski et al. (66) reported the ubiquity of MPs in returnable and single-use plastic bottles, beverage cartons, and glass bottles collected in Germany. Most (80\%) of the MPs in bottled water were PET and $\mathrm{PP}$ of 5-20 $\mu \mathrm{m}$ in size. The average MP contents in drinking water from returnable and single-use containers were 118 and 


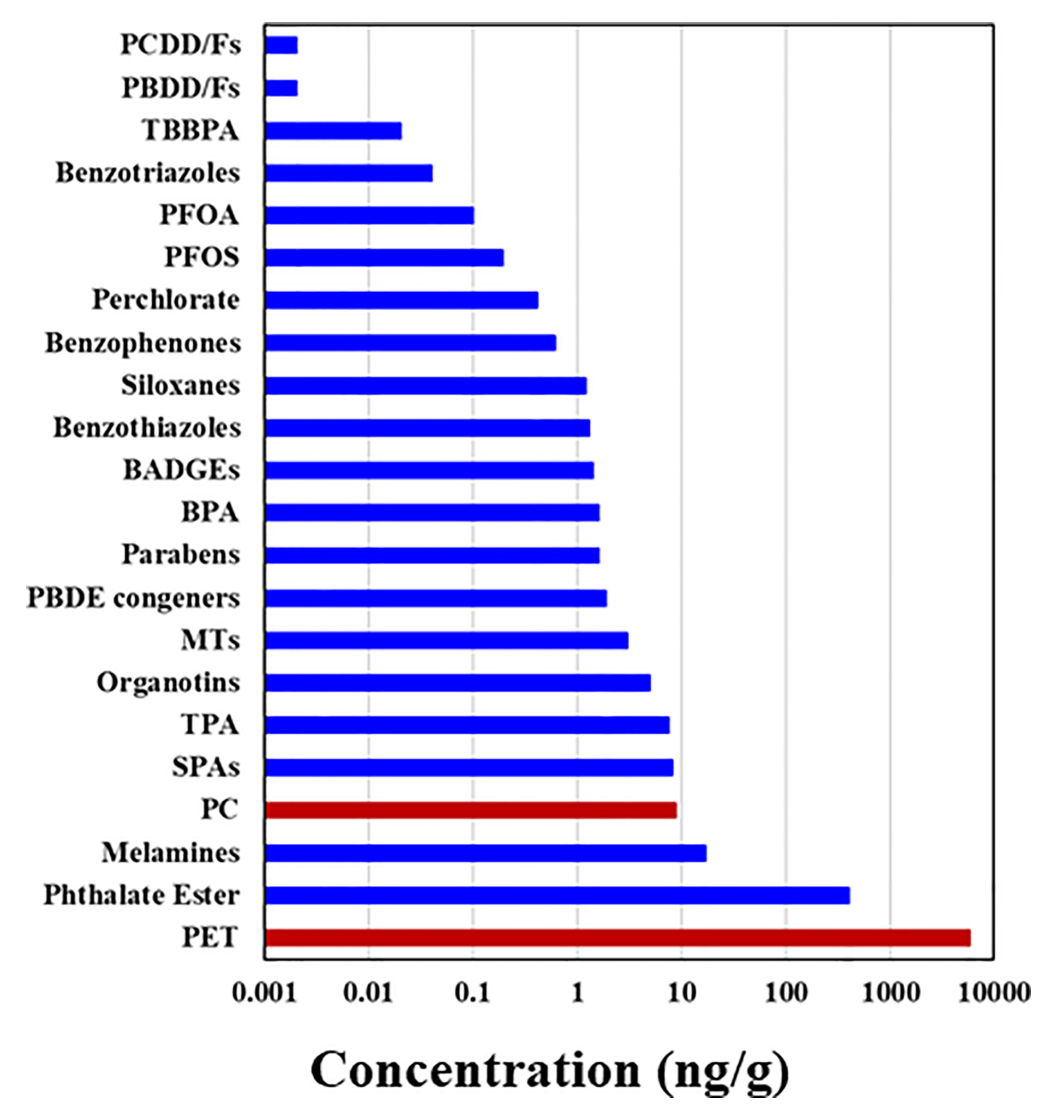

FIGURE 2 | Median concentrations of polyethylene terephthalate (PET) and polycarbonate (PC)-based microplastics measured in indoor dust samples collected from Albany, New York, USA, compared with those of other chemicals [see Zhang et al. (48) for details]; PCDD and PCDFs, polychlorinated dibenzo-p-dioxins and dibenzofurans, respectively; PBDD and PBDFs, polybrominated dibenzop-dioxins and dibenzofurans, respectively; TBBPA, tetrabromobisphenol A; PFOA, perfluorooctanoic acid; PFOS, perfluorooctanesulfonate; BADGEs, bisphenol A diglycidyl ether; PBDEs, polybrominated diphenyl ethers; MT, metabolites of 2,6-ditert-butyl-4-hydroxytoluene; SPAs, synthetic phenolic antioxidants; TPA, terephthalic acid.

14 particles/L, respectively. High concentrations of MPs found in bottled water were due to release from the plastic container itself. However, the German study showed that water bottled in glass also had notable levels of MPs (mean: 50 particles/L), and suggested that plastic caps used for glass bottles were the source of MPs.

Reported concentrations of MPs in drinking water vary by several orders of magnitude (Table 1) due to the varying analytical approaches used, especially with regard to the use of filter membranes with different pore sizes and different identification methods (e.g., FTIR, Raman, X-ray photoelectron, energy dispersive $\mathrm{x}$-ray spectroscopy, or scanning electron microscopy). This generally precludes direct comparison among studies of MP abundances reported in drinking water. In tap and bottled water, these vary between 0 and 10,000 particles/L (121), with plastic-bottled water containing higher concentrations of MPs $(0-10,000$ particles/L) than tap water $(0-61$ particles/L) $(65,71)$. Reported concentrations of MPs in tap water and bottled water from China, Thailand, Mexico, and Iran were in the range of 0-1247 particles/L, with average concentrations ranging from tens to hundreds of particles/L (Table 1).
In an exposure assessment, Cox et al. (45) used mean MP concentrations in bottled and tap water of 94 and 4.2 particles/L, respectively. On the basis of the average water consumption pattern, the mean daily intake of MPs through drinking water was estimated at $48,55,47$, and 51 MPs by male children, male adults, female children, and female adults, respectively (45). The calculated exposure dose from bottled water was 22-fold higher than that from tap water. It was estimated that an individual drinking exclusively bottled water would ingest 90,000 MPs/year, vs. just 4000 particles/year for someone ingesting only tap water. The authors suggested that avoiding the consumption of plasticbottled water might effectively reduce exposure to MPs (45), given that plastic-bottled water consumption is currently the second-greatest source of exposure to MPs globally.

Besides tap and bottled water, several studies have reported the occurrence of MPs in beverages such as beer, wine, energy drinks, and bottled tea. The concentrations of MPs in beer from Germany, the USA, and Mexico were in the ranges of 10-256, 014 , and 0-28 particles/L, respectively (122). White wine from Italy contained 2563-5857 MP particles/L (122). Similarly, MP levels of 11-40 particles/L have been reported in soft drinks, 
energy drinks, and tea from Mexico (122). Another study reported that a single plastic tea bag can release billions (12 billion per cup) of MPs when heated at $95^{\circ} \mathrm{C}(80)$, making these a significant source of MP exposure. The sources of MP contamination in beverages include source water, packaging material, and the packaging process.

Despite the small number of studies reporting MPs in drinking water, the results vary depending on the analytical methods and experimental protocols, which warrants harmonization of methods. Nevertheless, the ubiquity of MPs in drinking water and beverages is compelling and indicates that drinking water and beverages, especially those packaged in plastic containers, can be the second-largest source of human exposure, after inhalation. Indeed, for individuals consuming only bottled water and beverages packaged in plastic containers, daily MP exposure through this pathway can be higher than that from inhalation (45). More studies are needed to investigate MP concentrations in beverages and other drinks packaged in various types of containers.

\section{Diet}

Among dietary sources, MP contamination of seafood and sea salt has been studied extensively. These studies reported MP concentrations of up to 200,000 particles/kg (123). Among sea salt samples analyzed from various countries, Kim et al. (74) reported that MP concentrations in table salt from Asian countries were higher than those in table salt from other continents. Nevertheless, data from the analysis of MPs in sea salt are prone to discrepancies in analytical approaches, complicating inter-study comparability. Food products reported to contain MPs include bivalves, crustaceans, fish, seaweed, chicken, sugar, salt, and honey $(17,41,64,76,86,94$, 124-126). In 2016, the European Food Safety Authority (EFSA) published an overview of MPs and nanoplastics in food, with a focus on seafood (127). This report highlighted the occurrence of MPs in bivalves, shrimp/crab, and fish at concentration ranges of $0.2-4,0.75$, and 1-7 particles/g, respectively $(128,129)$. Contamination of honey (40-660 fibers/kg), sugar (217 fibers/ $\mathrm{kg}$ ), and salt (0-19,800 particles/kg) with MPs has been documented $(128,129)$. Cox et al. (45) used average concentrations in seafood of $1.48 \mathrm{MPs} / \mathrm{g}$, sugar of $0.44 \mathrm{MPs} / \mathrm{g}$, honey of $0.10 \mathrm{MPs} / \mathrm{g}$, and salt of $0.11 \mathrm{MPs} / \mathrm{g}$ in a human exposure assessment. Chickens raised in home gardens contained a mean of 63 and $11 \mathrm{MP}$ particles in gizzards and crops, respectively (130). In that study, MPs were identified in chicken feces. In addition, concentrations of MPs increased from soil (0.89 particles/g) to earthworm (15 particles/g) to chicken (130 particles/g). Globally, humans may ingest an average of $0.1-5$ g/week of MPs up to $1 \mathrm{~mm}$ in size, or 74,000-121,000 particles per year (45). However, the authors of that study noted that this could be an underestimate of actual exposures (45). Major food groups have not yet been analyzed for MP contamination. Furthermore, contamination and release of MPs from plastic food packaging materials are unknown, but could be high, as evidenced by the concentrations reported for plastic-bottled water. One study showed the release of 16 million MP particles/L from PP feeding bottles during sterilization, highlighting the urgent and critical need to assess MP exposure in infants (131). That study showed that exposure in infants fed with milk prepared in PP baby bottles can be as high as 3 million MPs per day. Similarly, steeping plastic tea bags in hot water at $95^{\circ} \mathrm{C}$ releases 2.3 million MP particles and 14.7 billion nanoparticles into a cup of tea $(41,132)$. Plastic food packaging could be another important source of MP exposure in humans (133), although little is known on this topic. Kedzierski et al. (134) analyzed the surface of packaged meat products (white chicken breast and turkey) and found PS MPs at concentrations ranging from 4.0 to 18.7 particles per $\mathrm{kg}$ of packaged meat. These MPs were found to stick to the meat surface before and after washing. The authors suggested that contamination with plastic particles was due to PS dust suspended in the air of the production facility. Besides food packaged in plastic wraps or containers, carryout fast food packaged in plastics could be a significant source of human exposure to MPs.

Kutralam-Muniasamy et al. (135) analyzed 23 dairy milk samples from Mexico and found an average of $6.5 \pm 2.3 \mathrm{MP}$ particles/L (range: 3-11 particles/L), with concentrations being higher in processed milk than in raw milk. The major source of MPs contamination in milk was reported to be sulfone polymers used in filtration in dairy industries $(135,136)$. The most common types of MPs found in food products were PET, PS, PE, PU, PVC, PP, polyamide, polymethyl methacrylate (PMMA; also known as acrylic or plexiglass), and styrene acrylate $(137,138)$.

The current understanding is that diet is the third most important source of human exposure to MPs, next to inhalation and drinking water ingestion. However, human diet has not been comprehensively evaluated for MP contamination. Considering the wide use of plastics in food packaging, the potential for dietary contributions to MP exposure is significant, and comprehensive studies are needed to assess MPs in various food products.

\section{Cosmetics and Textiles}

Plastic microbeads (i.e., MP particles generally $<1 \mathrm{~mm}$ ) have been widely used as abrasives in cosmetics, including scrubs and exfoliating soaps, shower gels, sunscreens, shaving foams, shampoos, skin creams, and liquid makeup (139). Hair bleaches, hair colorants, body lotions, lip care products, deodorants, and nail care products also contain microbeads. PE particles have been found in toothpaste and composite dental filling (140). MPs are added to cosmetics for skin exfoliation and cleansing and to deliver opacity, smooth and silky texture, illumination, and viscosity control (Cosmetics Europe 2019: https://cosmeticseurope.eu/news-events/cosmetics-europeannual-conference-2019). In 2014, 4130 tons of microbeads were used in soap in the EU countries annually (141). Approximately 93\% of microbeads used in cosmetics are PE, but they can also be made of PP, PET, PMMA, or nylon (141). Microbead contents in cosmetics vary widely, from $0.05 \%$ to $12 \%(117,141,142)$. On the basis of the amount present in liquid soaps, per capita consumption of MPs in the U.S. population was estimated at $2.4 \mathrm{mg}$ PE particles per day (143). Similarly, facial scrubs 
collected from the UK contained 1-10 $\mathrm{g}$ of PE microbeads per $100 \mathrm{~mL}$, and per capita consumption of PE MPs in facial scrubs was estimated at $0.5-215 \mathrm{mg} /$ day (144). It was estimated that between 4594 and 94,500 microbeads were released into the aquatic environment from a single use of a facial scrub (144).

Given this widespread occurrence of MPs in cosmetics, dermal exposure to MPs cannot be ruled out (145). Many cosmetics are directly applied to the skin, and particles $<100$ $\mathrm{nm}$ can cross the epithelial barrier. MPs used in cosmetics were evaluated by the Federal Institute for Risk Assessment of Germany, which concluded that MPs in these products can be associated with skin damage due to inflammation and cytotoxicity (146). Notably, MPs induce oxidative stress in human dermal epithelial cells.

The release of microfibers during washing of synthetic textiles has also been confirmed as a source of primary MPs in the environment (147). Over 700,000 microfibers were found to be released from a 6-kg wash load of acrylic fabric (147), and up to 13 million microfibers from polyester fabric in the first wash cycle (148). Use of face masks made of synthetic fibers during the Covid-19 pandemic may also have contributed to inhalation exposure to MPs from textiles. To date, no systematic investigations have been conducted to document human MP exposure from the use of cosmetics or synthetic textiles, and further studies are needed in both regards.

\section{PLASTIC ADDITIVES AS CO-CONTAMINANTS IN MPS}

A wide variety of additives and performance-enhancing chemicals (e.g., flame retardants, plasticizers, antioxidants, and light/heat stabilizers) are added to plastic polymers during production. These additives can leach from plastic debris or MPs released into the environment. An estimated 35-917 tons of additives are reported to be released into oceans annually (149), with PBDEs, phthalate esters, nonylphenol, and bisphenol A (BPA) being the commonly known plastic additives (150). The majority of these additives are present in plastic products at concentrations of up to $20 \% \mathrm{w} / \mathrm{w}$, although some plasticizers can be present at concentrations as high as $70 \% \mathrm{w} / \mathrm{w}$. Further details about additives have been described in earlier studies (150). It has been reported that over 10,000 chemicals are potentially used as plastic monomers, additives and processing aids, of which over 2400 were identified as substances of concern (151). Brominated flame retardants such as PBDEs, hexabromocyclododecane (HBCD), and tetrabromobisphenol A (TBBPA) have been widely used in plastics to reduce flammability. Owing to health concerns, these flame retardants were replaced by substitutes such as 1,2-bis $(2,4,6-$ tribromophenoxy)ethane (BTBPE), decabromodiphenylethane (DBDPE), and hexabromobenzene (HBB). More recently, organophosphate esters such as tri- $n$-butylphosphate (TnBP) have come into use as flame retardants and as plasticizers (imparting flexibility and malleability) in plastics. Phthalates such as di(2-ethylhexyl) phthalate (DEHP) are the most commonly used plasticizers in PVC plastic; 7.5 million tons of plasticizers are consumed globally every year, with DEHP accounting for $37 \%$ of this market (ECPI 2016: https://www.plasticisers.org/plasticisers/). Due to health and regulatory concerns, DEHP has gradually been replaced by diisononyl phthalate (DiNP), diisodecyl phthalate (DiDP), and di(2-propylheptyl) phthalate (DPHP), which collectively represented $57 \%$ of plasticizer consumption in Europe in 2015 (ECPI 2016: https://www.plasticisers.org/ plasticisers/). The most common plasticizers include esters such as adipates, azelates, citrates, benzoates, ortho-phthalates, terephthalates, sebacates, and trimellitates. BPA is a monomer used in the production of PC plastics that is produced at $>3$ million tons annually. BPA can also be used as an antioxidant or plasticizer in other plastic polymers (PP, PE, and PVC) (152). Other bisphenol analogs, such as bisphenol B, bisphenol $\mathrm{F}$, and bisphenol S, are also used in plastics (153). Nonylphenols (NP) are intermediates of the degradation of nonylphenol ethoxylates (NPE) surfactants and antioxidants (154) and are also used as antioxidants and plasticizers in plastics production (152). Many synthetic polymers also contain antioxidants that are used as additives/stabilizers, including polyolefins (mainly PE and PP), which represent $60 \%$ of the global demand for antioxidant additives (https://www.academia.edu/8665160/Polymer_Science). Phosphites are also widely used as antioxidants in plastics, serving to delay oxidation and prevent ageing of plastics (155); (https://www.solvay.com/en/chemical-categories/polymeradditives-uv-light-stabilizers-antioxidants-and-antistatic-agents/ brands-chemistries). Benzophenones, benzothiazoles, triazines, benzoxazinones, and benzotriazoles are widely used as UV stabilizers in plastics $(156,157)$. Similarly, quaternary ammonium salts are used as antistatic agents in plastics. Organotin compounds such as butyl-, phenyl-, methyl-, and octyltins are used as heat and light stabilizers in PVC plastics (158). Human exposures to phthalates $(159,160)$, bisphenols $(153,161)$, UV stabilizers such as organotins and benzotriazoles $(158,162)$, and brominated flame retardants (163) are well known. Further details of human exposures to these chemical additives found in plastics are provided in various publications listed above. It is important to note that exposure to MPs can contribute to and augment exposure to such additive chemicals.

\section{UPTAKE OF MPS AND OCCURRENCE IN HUMAN TISSUES}

The accumulation of plastic particles (PVC) of size 5-110 $\mu \mathrm{m}$ in animal models such as rats, dogs, and pigs was reported as early as 1970 (164). The size of MPs determines their uptake efficiency through gastrointestinal, alveolar, and dermal epithelium (165167). Once ingested, $>90 \%$ of MPs were reported to be excreted in feces (168), especially large particles $>150 \mu \mathrm{m}$; however, smaller particles may be absorbed systematically. It has been reported that MPs $0.1-10 \mu \mathrm{m}$ in size can cross the blood-brain barrier and the placenta (127), particles $<150 \mu \mathrm{m}$ can cross gastrointestinal epithelium, and particles $<2.5 \mu \mathrm{m}$ can enter the systemic circulation through endocytosis (33). In an engineered drug-delivery system, MPs $<5 \mu \mathrm{m}$ were shown accumulate in the 
macrophages and be carried to mesenteric lymph nodes, blood circulation, and spleen (169). Controlled exposure studies using human cells and rodents suggest that MPs of $<10 \mu \mathrm{m}$ can also be translocated from the gut to the circulatory system and accumulate in liver, kidney, and brain (170). The smallest particles $(<0.1 \mu \mathrm{m}$; i.e., nanoplastics $)$ can cross cell membranes, the placenta, and the blood-brain barrier (171). There is evidence for maternal transfer of MPs in exposed laboratory animals: Fournier et al. (128) demonstrated the translocation of 20-nm PS MPs from maternal lungs to fetus in exposed rats, and rats exposed to PS MPs via intratracheal instillation during gestation showed accumulation in maternal lungs, heart, placenta, and spleen and in the fetal liver, lungs, heart, kidney, and brain. Wick et al. (172) showed that PS MPs $240 \mathrm{~nm}$ in size can cross the placental barrier through diffusion or binding to cellular transport proteins. Although the intestinal absorption rate of MPs is low $(<1 \%)$, better insight into the uptake of MPs of various sizes, shapes, doses, and types is needed to understand the risks of MPs in humans. Similarly, little is known about the uptake and translocation of MPs through inhalation, although particles $<10 \mu \mathrm{m}$ have been found to be absorbed through alveolar epithelium. The molecular weight cut-off for biliary excretion of anionic chemicals has been reported as $500 \pm 50$ Da for humans $(173,174)$. In general, larger MPs are likely excreted through feces or through mucociliary clearance after deposition in lungs. Size, shape, dose, surface functionalization, and charge, as well as hydrophobicity, can affect the uptake, translocation, and accumulation of MPs (170). The toxicity of MPs increases with decrease in size (167).

Accumulation of plastic fibers in lungs was first reported in 1998 , with $87 \%$ of 114 malignant and non-neoplastic lung specimens found to contain MPs (115). This suggested that MPs can accumulate in lung tissues and could contribute to adverse health outcomes, including cancer. Like 2.5- $\mu \mathrm{m}$ airborne particulate matter $\left(\mathrm{PM}_{2.5}\right)$, MPs should be considered in future monitoring studies and exposure assessments. Earlier studies had reported the occurrence of plastic particles originating from prosthetic medical devices in tissues from patients; PE wear particles of up to $50 \mu \mathrm{m}$ were found in the liver, spleen, and abdominal lymph nodes of patients with hip or knee replacements (175). Studies have also reported the occurrence of MPs in human and pet animal stool specimens $(48,107)$. An analysis of stool from eight human volunteers ( 3 men and 5 women aged 33-65 years) from several countries for MPs 50-500 $\mu \mathrm{m}$ in size found an average of 20 pieces of MPs per $10 \mathrm{~g}$ of stool, with PP (62.8\%) and PE (17\%) being most widely identified. The average excretion rate of MPs in human stool was estimated at 25 particles per $100 \mathrm{~g}$ of stool (107). Similarly, the mass of PET and PC MPs was assessed in stools from pet dogs and cats with an excretion rate of calculated in the range of 0.03$677 \mathrm{mg} /$ week (48).

Biomonitoring studies of human body burdens of MPs are still in their infancy. A recent study that reported the occurrence of MPs in human placenta received considerable attention (46), given that they could affect the developing fetus. Ragusa et al. (46) analyzed six human placentas from Rome (Italy) by Raman microspectroscopy and reported $12 \mathrm{MP}$ fragments $(5-10 \mu \mathrm{m})$ in four of them. All of the MPs were pigmented, and three were identified as PP. The authors hypothesized that MPs in placenta could affect major cellular pathways involved in the immune system, growth factor signaling, and several other systems. A recent study from Malaysia reported the occurrence of MPs in colon at concentrations of 331 particles per specimen or $28 \pm 15$ particles per g colon, with PC being most abundant, followed by polyamide and PP (176).

Overall, there is convincing evidence that exposure to and accumulation of MPs in human tissues is prevalent. Particles $<100 \mu \mathrm{m}$ can cross cell membranes of exposed tissues/cells/ laboratory animals, and particles $<20 \mu \mathrm{m}$ may be efficiently translocated into various organs. Although research in this area is at its infancy, the available evidence points to an urgent need for studies on the uptake, accumulation and health effects of MP exposure in humans.

\section{TOXIC MECHANISMS OF MICROPLASTICS IN RELATION TO OBESITY}

Little is known about the potential toxic effects of MPs in humans. However, it is reported that when inhaled or ingested, MPs $<20 \mu \mathrm{m}$ in size can penetrate biological membranes, accumulate in tissues, and elicit cytotoxic and immune responses. Exposure of laboratory animals or cell cultures to MPs results in inflammation, cytotoxicity (e.g., oxidative stress, cells injury, cell viability, altered membrane function; 177, 178), genotoxicity (through oxidative damage; 179), and immunotoxicity (180) at the cellular level. MPs can be engulfed by endocytes, and thus reach the cytosol and interact with organelles such as mitochondria and nucleus, causing disruption of cellular processes. Most studies indicate that these responses to MPs are mediated by oxidative stress. For example, Deng et al. (181) reported oxidative stress in mouse liver following exposure to PS MPs. Oxidative stress could aggravate abnormal lipid metabolism, among various adverse health outcomes (Table 2). Several of the observed toxic effects of MPs are intricately interconnected, such that disturbance of one process may initiate a cascade of other toxicological responses. Although there is still a paucity of data on the health risks of MPs in humans, there is sufficient evidence to necessitate a precautionary approach in dealing with such exposures. It is also worth to note that the European Commission's Science Advice for Policy (SAPEA 2016: https://www.sapea.info/ wp-content/uploads/report.pdf) and the World Health Organization (WHO 2019: https://www.who.int/publications/i/ item/9789241516198) reported that currently no evidence exists for direct adverse effects of MPs on human health. Furthermore, few available observations were mostly based on in vitro and laboratory animal studies. A few review articles have reported toxic effects of MPs; here, we focus specifically on the potential the toxic effects related to obesogenic mechanisms. 
TABLE 2 | Toxic effects of microplastics as related to obesogenic effects in laboratory animals (mostly mice).

\begin{tabular}{|c|c|c|c|}
\hline $\begin{array}{l}\text { Type of microplastics } \\
\text { and dosage }\end{array}$ & $\begin{array}{l}\text { Tissue accumulation } \\
\text { and uptake }\end{array}$ & Toxic effect & Reference \\
\hline $\begin{array}{l}\text { PS microspheres } 5 \text { and } 20 \mu \mathrm{m} \text {, } \\
0.01-0.5 \mathrm{mg} / \text { day }\end{array}$ & $\begin{array}{l}\text { Accumulation in gut, liver } \\
\text { and kidney }\end{array}$ & $\begin{array}{l}\text { Changes in lipid profile and improper energy metabolism (reduction in ATP levels), } \\
\text { and fatty liver }\end{array}$ & $(181)$ \\
\hline PS particle (0.5 and $50 \mu \mathrm{m})$ & & $\begin{array}{l}\text { Decreased body, liver and lipid weight, altered gut microbiota, and changes in lipid } \\
\text { metabolism }\end{array}$ & $(182)$ \\
\hline$P S$ and $P E(0.5-1.0 \mu m)$ & $\begin{array}{l}\text { PS and PE beads found in } \\
\text { gut and liver }\end{array}$ & Metabolic disorder & $(183)$ \\
\hline $\begin{array}{l}\text { PS (5 } \mu \mathrm{m} \text { with doses } 100 \text { and } \\
1000 \mu \mathrm{g} / \mathrm{L})\end{array}$ & $\begin{array}{l}\text { Accumulation in mouse gut } \\
\text { part }\end{array}$ & Gut microbiota dysbiosis, bile acids metabolism disorder & $(184)$ \\
\hline PS (5 and $20 \mu \mathrm{m})$ & $\begin{array}{l}\text { Accumulation in gut, liver } \\
\text { and kidney }\end{array}$ & Changes in ATP synthesis and lipid metabolism & $(185)$ \\
\hline PS $(5 \mu m)$ & & $\begin{array}{l}\text { Altered serum and liver markers, changes of metabolic disorder in the gut and } \\
\text { glycolipid metabolism, maternal exposure caused metabolic effects in F1 and F2 } \\
\text { generations showing transgeneration effects }\end{array}$ & $(186)$ \\
\hline PS $(0.5$ and $5 \mu \mathrm{m})$ & & $\begin{array}{l}\text { Changes in serum and liver metabolic markers and maternal exposure caused fatty } \\
\text { acid metabolic disorder in the F1 offspring }\end{array}$ & $(186)$ \\
\hline 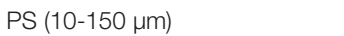 & & Affect the diversity of gut microbiota & $(187)$ \\
\hline
\end{tabular}

It is suggestive that over the past five decades, the prevalence of obesity/overweight has increased by three-fold worldwide, which is in congruence with the use of plastics (Figure 1). According to the WHO, 39\% of adults worldwide were overweight and $13 \%$ were obese among those aged $\geq 18$ years in 2016 (http://www.who.int/news-room/fact-sheets/detail/ obesity-and-overweight). Overweight and obesity are also on the rise among children, with approximately $30 \%$ of U.S. children grouped into those categories in 2013. Although this has been attributed to factors such as excessive caloric intake, inadequate physical activity, and sedentary lifestyle, exposure to environmental contaminants is also proposed to play an important role $(188,189)$. Data from the National Health and Nutrition Examination Survey (NHANES) showed that caloric intake and energy expenditure were similar in US adults between 1988 and 2006, although there was a $2.3 \mathrm{~kg} / \mathrm{m}^{2}$ increase in BMI between the two periods (190). Thus, diet alone cannot explain the increase in BMI in recent years. We hypothesize that the global obesity pandemic is associated with exposure to obesogens including MPs and plastic additives. Obesogens are defined as chemicals that lead to increased white adipose tissue accumulation, in vivo, after exposure (191). Obesogens affect the differentiation of white adipocytes (192). MPs have been shown to affect adipocyte differentiation following accumulation in liver and kidney and alterations in energy balance and lipid metabolism (181). A few studies that reported obesogenic effects of MPs are listed in Table 2. The majority were focused on PS MPs, with little known about the effects of PP, PET, and other types of MPs-topics that also merit investigation. Deng et al. (181) reported decreases in triglyceride and total cholesterol levels in mouse liver following exposure to 5 and $20 \mu \mathrm{m}$ PS MPs, and confirmed that MPs induced lipid metabolism imbalance and metabolic alterations, including decreases in ATP production and lipid metabolism (181). Changes in liver lipid profiles and lipid metabolism following exposure to PS MPs have been documented in several other in vivo mouse exposure studies and in vitro human cell bioassays $(166,182,185,186,193)$.
Exposure of mice to PS MPs decreased mRNA levels of key genes involved in lipogenesis and triglyceride synthesis in mouse liver and epididymal fat (182). Jin et al. (184) reported alterations in transcriptional levels of CYP7a1 and ABCb11, two proteins involved in bile acid synthesis and transport in the livers of mice exposed to 5- $\mu \mathrm{m}$ PS MPs. Bile acid plays an important role in lipid metabolism. Maternal exposure to PS MPs during gestation can cause metabolic disorders in the offspring (166), which suggested epigenetic changes and transgenerational effects from MP exposure. These results have considerable implications in regard to early life MP exposure and metabolic alterations and obesity in humans. Other metabolic disorders reported following exposure to MPs in laboratory animals include those affecting energy and bile acid metabolism, as well as alterations in gut microbiota $(128,181,185)$. Gut microbiota dysbiosis is a common effect of MPs found in several laboratory mouse studies $(128,166,182,187)$. Changes in gut microbiota can perturb physiological homeostasis, leading to diseases in other organs such as kidney disorders (194), cardiovascular system disorders (195), inflammation and cancer (196), and neurological disorders (197). Various molecular mechanisms leading to obesogenic effects of MPs and plastic additives are outlined in Figure 3. Further studies are needed to confirm obesogenic effects of MPs and plastic additives.

In addition to the particle toxicity induced by MPs, the indirect toxicity caused by the release of additives and monomers is of considerable importance. One of the most well characterized obesogens is organotins, which are used as heat and light stabilizers in PVC (198). Butyltins bind to PPAR $\gamma$ and RXR at $\mathrm{nM}$ concentrations, promoting adipogensis and lipid accumulation (191). Plastic additives such as phthalates and bisphenols have been reported to affect adipogenesis and energy balance (199). Monoethylhexyl phthalate (MEHP) and diethylhexyl phthalate (DEHP), induced adipogenesis via activation of PPAR $\gamma$ (200). BPA, another plastic additive, may bind to estrogen receptors and interfere with estrogen signaling to elicit obesogenic effects (201). Similarly, UV filters such as 


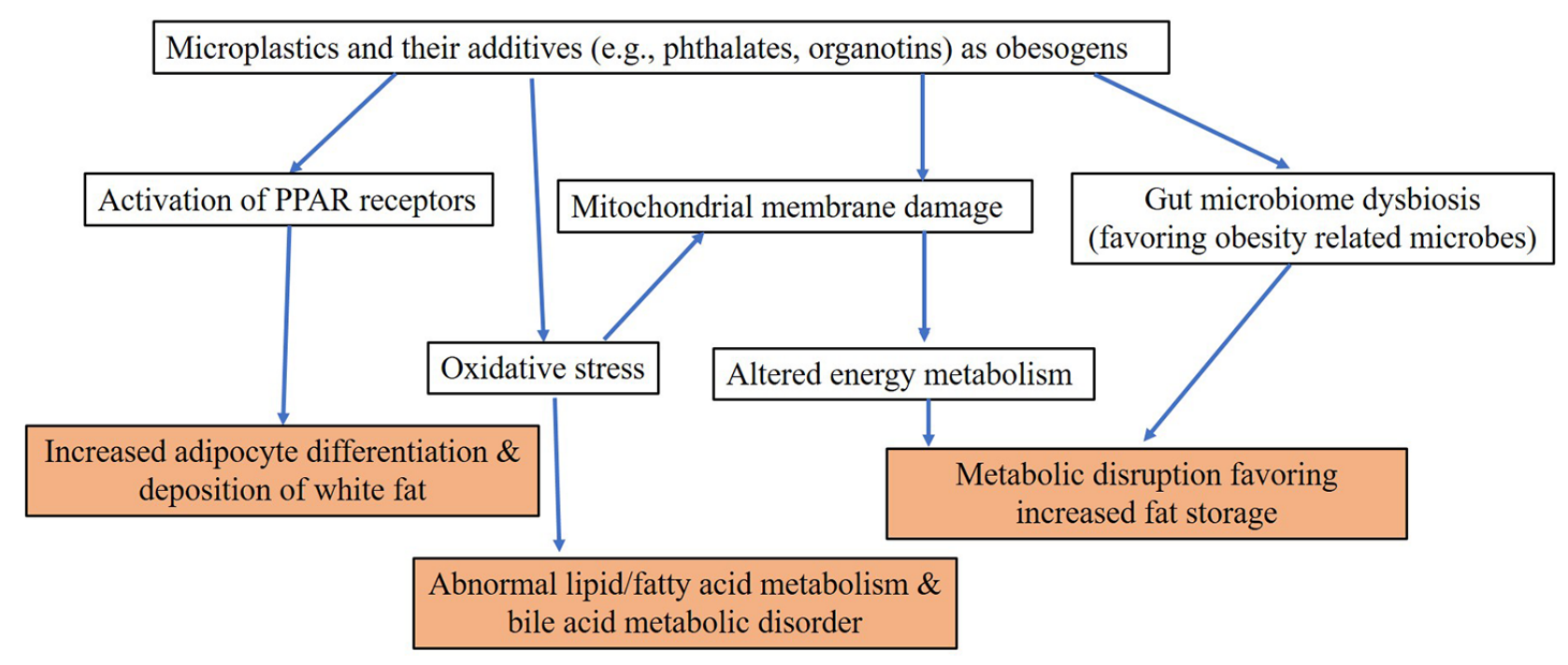

FIGURE 3 | Proposed mechanisms of obesogenic effects of microplastics and their additives.

benzotriazoles (202), flame retardants such as HBCD (203) and BPA (204) have been shown to affect adipogenesis in laboratory animals. Obesogens are believed to act through binding to PPAR isoforms that results in a cascade of activities affecting cellular functions. In general, environmental obesogens activate PPAR $\gamma$ and its heterodimeric partner, the retinoid $\mathrm{X}$ receptor alpha $(\mathrm{RXR} \alpha)$. PPAR $\gamma$ is considered the master regulator of adipogenesis: its activation increases the expression of adipogenic genes, promotes adipogenic differentiation and increases lipid accumulation. Phthalates, bisphenols, organotins, and HBCD have been identified as PPAR agonists and contributors to obesogenic effects (205), pointing to potential mechanisms whereby plastic additives released from MPs could contribute to obesity. Recent studies have demonstrated other novel mechanisms of obesogenic action, which include induction of epigenetic modification in fat tissue and induction of gut microbiome dysbiosis (191). It is intriguing to note that some studies have reported trans-generational effects of obesogens including MPs $(166,206)$. It was shown that obesogenic effects of tributyltin were transgenerational and was detected in the F1, F2, F3, and F4 descendants of F0 mice exposed during pregnancy (207). Thus, trans-generational effects of MPs are a concern and subject of further studies.

\section{CONCLUSIONS}

MPs are pervasive in the global environment and have reached every compartment of the human food chain. Human exposure to this class of chemicals is widespread and likely to increase, unless adequate mitigation strategies can be implemented.
Evidence suggests that MPs of size $<20 \mu \mathrm{m}$ can penetrate organs, and MPs $<10 \mu \mathrm{m}$ can penetrate cell membranes and cross the placental barrier in exposed cells or laboratory animals. Despite this, little is known about the toxic effects of MPs in humans, which might vary depending on the type, size, shape, concentration, and charge of MPs, among other factors. More research is therefore very much needed to understand the cellular and molecular mechanisms of MP toxicity and associated pathology. MPs and several additives associated with their component plastics are obesogenic compounds and that further research is needed to tease out the mechanisms involved and potential means to mitigate these effects. Because MPs and their additives may have multigenerational or transgenerational effects, further efforts to elucidate their mode of toxicity and mitigation of exposures should be an urgent public health goal.

\section{AUTHOR CONTRIBUTIONS}

KK - wrote the review, data analysis, and figures. KV - reviewed the document, organized references, and prepared tables. All authors contributed to the article and approved the submitted version.

\section{FUNDING}

The research reported in this manuscript was supported in part by the National Institute of Environmental Health Sciences (NIEHS) under Award Number U2CES026542. 


\section{REFERENCES}

1. Dris R, Gasperi J, Saad M, Mirande C, Tassin B. Synthetic Fibers in Atmospheric Fallout: A Source of Microplastics in the Environment? Mari Pollut Bull (2016) 104(1-2):290-3. doi: 10.1016/j.marpolbul.2016.01.006

2. Qiu Q, Peng J, Yu X, Chen F, Wang J, Dong F. Occurrence of Microplastics in the Coastal Marine Environment: First Observation on Sediment of China. Mari Pollut Bull (2015) 98(1-2):274-80. doi: 10.1016/j. marpolbul.2015.07.028

3. Su L, Xue Y, Li L, Yang D, Kolandhasamy P, Li D, et al. Microplastics in Taihu Lake, China. Environ Pollut (2016) 216:711-9. doi: 10.1016/j.envpol.2016.06.036

4. Teng J, Wang Q, Ran W, Wu D, Liu Y, Sun S, et al. Microplastic in Cultured Oysters From Different Coastal Areas of China. Sci Total Environ (2019) 653:1282-92. doi: 10.1016/j.scitotenv.2018.11.057

5. Zhang $\mathrm{K}$, Xiong $\mathrm{X}, \mathrm{Hu} \mathrm{H}, \mathrm{Wu} \mathrm{C}, \mathrm{Bi} \mathrm{Y}, \mathrm{Wu} \mathrm{Y}$, et al. Occurrence and Characteristics of Microplastic Pollution in Xiangxi Bay of Three Gorges Reservoir, China. Environ Sci Technol (2017) 51(7):3794-801. doi: 10.1021/ acs.est.7b00369

6. Geyer R, Jambeck JR, Law KL. Production, Use, and Fate of All Plastics Ever Made. Sci Adv (2017) 3(7):e1700782. doi: 10.1126/sciadv.1700782

7. Li J, Qu X, Su L, Zhang W, Yang D, Kolandhasamy P, et al. Microplastics in Mussels Along the Coastal Waters of China. Environ Pollut (2016) 214:17784. doi: 10.1016/j.envpol.2016.04.012

8. Andrady AL, Neal MA. Applications and Societal Benefits of Plastics. Philo Trans Roy Soci B Bio Sci (2009) 364(1526):1977-84. doi: 10.1098/rstb.2008.0304

9. Thompson J. Handbook of Eating Disorders and Obesity. University of South Florida, Tampa, FL: John Wiley \& Sons Inc (2004).

10. Street ME, Bernasconi S. Microplastics, Environment and Child Health. Ital J Pediatr (2021) 47(1):1-3. doi: 10.1186/s13052-021-01034-3

11. Sharma S, Basu S, Shetti NP, Nadagouda MN, Aminabhavi TM. Microplastics in the Environment: Occurrence, Perils, and Eradication. Chem Eng J (2020) 408:127317. doi: 10.1016/j.cej.2020.127317

12. Abbasi S, Keshavarzi B, Moore F, Turner A, Kelly FJ, Dominguez AO, et al. Distribution and Potential Health Impacts of Microplastics and Microrubbers in Air and Street Dusts From Asaluyeh County, Iran. Environ Pollut (2019) 244:153-64. doi: 10.1016/j.envpol.2018.10.039

13. Bhattacharya P. A Review on the Impacts of Microplastic Beads Used in Cosmetics. Act Biomedi Sci (2016) 3(1):47-52.

14. Juliano C, Magrini GA. Cosmetic Ingredients as Emerging Pollutants of Environmental and Health Concern. A Mini-Review. Cosmetics (2017) 4 (2):11. doi: 10.3390/cosmetics4020011

15. Patel MM, Goyal BR, Bhadada SV, Bhatt JS, Amin AF. Getting Into the Brain. CNS Drugs (2009) 23(1):35-58. doi: 10.2165/0023210-200923010-00003

16. Lei K, Qiao F, Liu Q, Wei Z, Qi H, Cui S, et al. Microplastics Releasing From Personal Care and Cosmetic Products in China. Mari Pollut Bull (2017) 123 (1-2):122-6. doi: 10.1016/j.marpolbul.2017.09.016

17. Karbalaei S, Hanachi P, Walker TR, Cole M. Occurrence, Sources, Human Health Impacts and Mitigation of Microplastic Pollution. Environ Sci Pollut Res (2018) 25(36):36046-63. doi: 10.1007/s11356-018-3508-7

18. Andrady AL. Microplastics in the Marine Environment. Mari Pollut Bull (2011) 62(8):1596-605. doi: 10.1016/j.marpolbul.2011.05.030

19. Zettler ER, Mincer TJ, Amaral-Zettler LA. Life in the "Plastisphere": Microbial Communities on Plastic Marine Debris. Environ Sci Technol (2013) 47(13):7137-46. doi: 10.1021/es401288x

20. Arthur C, Baker JE, Bamford HA. Proceedings of the International Research Workshop on the Occurrence, Effects, and Fate of Microplastic Marine Debris, September 9-11, 2008. USA: University of Washington Tacoma, Tacoma, WA (2009).

21. Rillig MC. Microplastic in Terrestrial Ecosystems and the Soil? Environ Sci Technol (2012) 46(12):6453-4. doi: 10.1021/es302011r

22. Gigault J, Ter Halle A, Baudrimont M, Pascal P-Y, Gauffre F, Phi T-L, et al. Current Opinion: What Is a Nanoplastic? Environ Pollut (2018) 235:1030-4. doi: 10.1016/j.envpol.2018.01.024

23. Journal EPoCitFCJE. Presence of Microplastics and Nanoplastics in Food, With Particular Focus on Seafood. J EFSA (2016) 14(6):e04501. doi: 10.2903/ j.efsa.2016.4501

24. Calafat AM, Kuklenyik Z, Reidy JA, Caudill SP, Ekong J, Needham LL. Urinary Concentrations of Bisphenol A and 4-Nonylphenol in a Human
Reference Population. Environ Health Perspect (2005) 113(4):391-5. doi: 10.1289/ehp.7534

25. Sjödin A, Päpke O, McGahee E, Focant J-F, Jones RS, Pless-Mulloli T, et al. Concentration of Polybrominated Diphenyl Ethers (PBDEs) in Household Dust From Various Countries. Chemosphere (2008) 73(1):S131-6. doi: $10.1016 /$ j.chemosphere.2007.08.075

26. Kumar P. Role of Plastics on Human Health. Ind J Pediatr (2018) 85(5):3849. doi: 10.1007/s12098-017-2595-7

27. Jang M, Shim WJ, Han GM, Rani M, Song YK, Hong SH. Widespread Detection of a Brominated Flame Retardant, Hexabromocyclododecane, in Expanded Polystyrene Marine Debris and Microplastics From South Korea and the Asia-Pacific Coastal Region. Environ Pollut (2017) 231:785-94. doi: 10.1016/j.envpol.2017.08.066

28. Fries E, Zarfl C. Sorption of Polycyclic Aromatic Hydrocarbons (PAHs) to Low and High Density Polyethylene (PE). Environ Sci Pollut Res (2012) 19 (4):1296-304. doi: 10.1007/s11356-011-0655-5

29. Ogata $Y$, Takada H, Mizukawa K, Hirai H, Iwasa S, Endo S, et al. International Pellet Watch: Global Monitoring of Persistent Organic Pollutants (POPs) in Coastal Waters. 1. Initial Phase Data on PCBs, DDTs, and HCHs. Mari Pollut Bull (2009) 58(10):1437-46. doi: 10.1016/j.marpolbul.2009.06.014

30. Velzeboer I, Kwadijk C, Koelmans A. Strong Sorption of PCBs to Nanoplastics, Microplastics, Carbon Nanotubes, and Fullerenes. Environ Sci Technol (2014) 48(9):4869-76. doi: 10.1021/es405721v

31. Holmes LA, Turner A, Thompson RC. Adsorption of Trace Metals to Plastic Resin Pellets in the Marine Environment. Environ Pollut (2012) 160:42-8. doi: $10.1016 /$ j.envpol.2011.08.052

32. Fries E, Dekiff JH, Willmeyer J, Nuelle M-T, Ebert M, Remy D. Identification of Polymer Types and Additives in Marine Microplastic Particles Using Pyrolysis-GC/MS and Scanning Electron Microscopy. Environ Sci Process Impacts (2013) 15(10):1949-56. doi: 10.1039/C3EM00214D

33. Campanale C, Massarelli C, Savino I, Locaputo V, Uricchio VF. A Detailed Review Study on Potential Effects of Microplastics and Additives of Concern on Human Health. Int J Environ Res Public Health (2020) 17(4):1212. doi: $10.3390 /$ ijerph 17041212

34. Carbery M, O'Connor W, Palanisami T. Trophic Transfer of Microplastics and Mixed Contaminants in the Marine Food Web and Implications for Human Health. Environ Int (2018) 115:400-9. doi: 10.1016/j.envint.2018.03.007

35. Browne MA, Crump P, Niven SJ, Teuten E, Tonkin A, Galloway T, et al. Accumulation of Microplastic on Shorelines Woldwide: Sources and Sinks. Environ Sci Technol (2011) 45(21):9175-9. doi: 10.1021/es201811s

36. Rodrigues M, Abrantes N, Gonçalves F, Nogueira H, Marques J, Gonçalves A. Spatial and Temporal Distribution of Microplastics in Water and Sediments of a Freshwater System (Antuã River, Portugal). Sci Total Environ (2018) 633:1549-59. doi: 10.1016/j.scitotenv.2018.03.233

37. Imhof HK, Wiesheu AC, Anger PM, Niessner R, Ivleva NP, Laforsch C Variation in Plastic Abundance at Different Lake Beach Zones-A Case Study. Sci Total Environ (2018) 613:530-7. doi: 10.1016/j.scitotenv.2017.08.300

38. Horton AA, Walton A, Spurgeon DJ, Lahive E, Svendsen C. Microplastics in Freshwater and Terrestrial Environments: Evaluating the Current Understanding to Identify the Knowledge Gaps and Future Research Priorities. Sci Total Environ (2017) 586:127-41. doi: 10.1016/j.scitotenv.2017.01.190

39. Murphy F, Ewins C, Carbonnier F, Quinn B. Wastewater Treatment Works (WwTW) as a Source of Microplastics in the Aquatic Environment. Environ Sci Technol (2016) 50(11):5800-8. doi: 10.1021/acs.est.5b05416

40. Waller CL, Griffiths HJ, Waluda CM, Thorpe SE, Loaiza I, Moreno B, et al. Microplastics in the Antarctic Marine System: An Emerging Area of Research. Sci Total Environ (2017) 598:220-7. doi: 10.1016/ j.scitotenv.2017.03.283

41. Karami A, Golieskardi A, Choo CK, Larat V, Galloway TS, Salamatinia B. The Presence of Microplastics in Commercial Salts From Different Countries. Sci Rep (2017) 7(1):1-11. doi: 10.1038/srep46173

42. Prata JC. Airborne Microplastics: Consequences to Human Health? Environ Pollut (2018) 234:115-26. doi: 10.1016/j.envpol.2017.11.043

43. Vianello A, Jensen RL, Liu L, Vollertsen J. Simulating Human Exposure to Indoor Airborne Microplastics Using a Breathing Thermal Manikin. Sci Rep (2019) 9(1):1-11. doi: 10.1038/s41598-019-45054-w

44. Raju S, Carbery M, Kuttykattil A, Senathirajah K, Subashchandrabose S, Evans G, et al. Transport and Fate of Microplastics in Wastewater Treatment 
Plants: Implications to Environmental Health. Rev Environ Sci Bio Technol (2018) 17(4):637-53. doi: 10.1007/s11157-018-9480-3

45. Cox KD, Covernton GA, Davies HL, Dower JF, Juanes F, Dudas SE. Human Consumption of Microplastics. Environ Sci Technol (2019) 53(12):7068-74. doi: 10.1021/acs.est.9b01517

46. Ragusa A, Svelato A, Santacroce C, Catalano P, Notarstefano V, Carnevali O, et al. Plasticenta: First Evidence of Microplastics in Human Placenta. Environ Int (2021) 146:106274. doi: 10.1016/j.envint.2020.106274

47. Senathirajah K, Attwood S, Bhagwat G, Carbery M, Wilson S, Palanisami T. Estimation of the Mass of Microplastics Ingested-A Pivotal First Step Towards Human Health Risk Assessment. J Hazard Mater (2021) 404:124004. doi: 10.1016/j.jhazmat.2020.124004

48. Zhang J, Wang L, Kannan K. Polyethylene Terephthalate and Polycarbonate Microplastics in Pet Food and Feces From the United States. Environ Sci Technol (2019) 53(20):12035-42. doi: 10.1021/acs.est.9b03912

49. Catarino AI, Macchia V, Sanderson WG, Thompson RC, Henry TB. Low Levels of Microplastics (MP) in Wild Mussels Indicate That MP Ingestion by Humans Is Minimal Compared to Exposure via Household Fibres Fallout During a Meal. Environ Pollut (2018) 237:675-84. doi: 10.1016/ j.envpol.2018.02.069

50. Dris R, Gasperi J, Mirande C, Mandin C, Guerrouache M, Langlois V, et al. A First Overview of Textile Fibers, Including Microplastics, in Indoor and Outdoor Environments. Environ Pollut (2017) 221:453-8. doi: 10.1016/ j.envpol.2016.12.013

51. Brahney J, Hallerud M, Heim E, Hahnenberger M, Sukumaran S. Plastic Rain in Protected Areas of the United States. Sci (2020) 368(6496):1257-60. doi: 10.1126/science.aaz5819

52. Klein M, Fischer EK. Microplastic Abundance in Atmospheric Deposition Within the Metropolitan Area of Hamburg, Germany. Sci Total Environ (2019) 685:96-103. doi: 10.1016/j.scitotenv.2019.05.405

53. Allen S, Allen D, Phoenix VR, Le Roux G, Jiménez PD, Simonneau A, et al. Atmospheric Transport and Deposition of Microplastics in a Remote Mountain Catchment. Nat Geosci (2019) 12(5):339-44. doi: 10.1038/ s41561-019-0335-5

54. Cai L, Wang J, Peng J, Tan Z, Zhan Z, Tan X, et al. Characteristic of Microplastics in the Atmospheric Fallout From Dongguan City, China: Preliminary Research and First Evidence. Environ Sci Pollut Res (2017) 24 (32):24928-35. doi: 10.1007/s11356-017-0116-x

55. Zhou Q, Tiian C, Luo Y. Various Forms and Deposition Fluxes of Microplastics Identified in the Coastal Urban Atmosphere. Sci Bull (2017) 62(33):3902-9. doi: 10.1360/N972017-00956

56. Dris R, Gasperi J, Rocher V, Saad M, Renault N, Tassin B. Microplastic Contamination in an Urban Area: A Case Study in Greater Paris. Environ Chem (2015) 12(5):592-9. doi: 10.1071/EN14167

57. Akhbarizadeh R, Dobaradaran S, Torkmahalleh MA, Saeedi R, Aibaghi R, Ghasemi FF. Suspended Fine Particulate Matter (PM2. 5), Microplastics (MPs), and Polycyclic Aromatic Hydrocarbons (PAHs) in Air: Their Possible Relationships and Health Implications. Environ Res (2021) 192:110339. doi: 10.1016/j.envres.2020.110339

58. Zhang J, Wang L, Kannan K. Microplastics in House Dust From 12 Countries and Associated Human Exposure. Environ Int (2020) 134:105314. doi: 10.1016/j.envint.2019.105314

59. Zhang Q, Zhao Y, Du F, Cai H, Wang G, Shi H. Microplastic Fallout in Different Indoor Environments. Environ Sci Technol (2020) 54(11):6530-9. doi: 10.1021/acs.est.0c00087

60. Bahrina I, Syafei AD, Satoto R, Jiang J-J, Nurasrin NR, Assomadi AF, et al. An Occupant-Based Overview of Microplastics in Indoor Environments in the City of Surabaya, Indonesia. J Ecol Eng (2020) 21(8):236-42. doi: $10.12911 / 22998993 / 126876$

61. Liu C, Li J, Zhang Y, Wang L, Deng J, Gao Y, et al. Widespread Distribution of PET and PC Microplastics in Dust in Urban China and Their Estimated Human Exposure. Environ Int (2019) 128:116-24. doi: 10.1016/j.envint.2019.04.024

62. Kankanige D, Babel S. Smaller-Sized Micro-Plastics (MPs) Contamination in Single-Use PET-Bottled Water in Thailand. Sci Total Environ (2020) 717:137232. doi: 10.1016/j.scitotenv.2020.137232

63. Zuccarello P, Ferrante M, Cristaldi A, Copat C, Grasso A, Sangregorio D, et al. Exposure to Microplastics $(<10 \mu \mathrm{m})$ Associated to Plastic Bottles
Mineral Water Consumption: The First Quantitative Study. Water Res (2019) 157:365-71. doi: 10.1016/j.watres.2019.03.091

64. Oßmann BE, Sarau G, Holtmannspötter H, Pischetsrieder M, Christiansen SH, Dicke W. Small-Sized Microplastics and Pigmented Particles in Bottled Mineral Water. Water Res (2018) 141:307-16. doi: 10.1016/j.watres. 2018.05.027

65. Mason SA, Welch VG, Neratko J. Synthetic Polymer Contamination in Bottled Water. Front Chem (2018) 6:2018.00407. doi: 10.3389/ fchem.2018.00407

66. Schymanski D, Goldbeck C, Humpf H-U, Fürst P. Analysis of Microplastics in Water by Micro-Raman Spectroscopy: Release of Plastic Particles From Different Packaging Into Mineral Water. Water Res (2018) 129:154-62. doi: 10.1016/j.watres.2017.11.011

67. Wiesheu AC, Anger PM, Baumann T, Niessner R, Ivleva NP. Raman Microspectroscopic Analysis of Fibers in Beverages. Anal Methods (2016) 8(28):5722-5. doi: 10.1039/C6AY01184E

68. Shruti V, Pérez-Guevara F, Kutralam-Muniasamy G. Metro Station Free Drinking Water Fountain-A Potential "Microplastics Hotspot" for Human Consumption. Environ Pollut (2020) 261:114227. doi: 10.1016/ j.envpol.2020.114227

69. Zhang M, Li J, Ding H, Ding J, Jiang F, Ding NX, et al. Distribution Characteristics and Influencing Factors of Microplastics in Urban Tap Water and Water Sources in Qingdao, China. Anal Lett (2020) 53 (8):1312-27. doi: 10.1080/00032719.2019.1705476

70. Mintenig S, Löder M, Primpke S, Gerdts G. Low Numbers of Microplastics Detected in Drinking Water From Ground Water Sources. Sci Total Environ (2019) 648:631-5. doi: 10.1016/j.scitotenv.2018.08.178

71. Kosuth M, Mason SA, Wattenberg EV. Anthropogenic Contamination of Tap Water, Beer, and Sea Salt. PloS One (2018) 13(4):e0194970. doi: 10.1371/ journal.pone.0194970

72. Pivokonsky M, Cermakova L, Novotna K, Peer P, Cajthaml T, Janda V. Occurrence of Microplastics in Raw and Treated Drinking Water. Sci Total Environ (2018) 643:1644-51. doi: 10.1016/j.scitotenv.2018.08.102

73. Tong $\mathrm{H}$, Jiang $\mathrm{Q}, \mathrm{Hu} \mathrm{X}$, Zhong $\mathrm{X}$. Occurrence and Identification of Microplastics in Tap Water From China. Chemosphere (2020) 252:126493. doi: 10.1016/j.chemosphere.2020.126493

74. Kim J-S, Lee H-J, Kim S-K, Kim H-J. Global Pattern of Microplastics (MPs) in Commercial Food-Grade Salts: Sea Salt as an Indicator of Seawater MP Pollution. Environ Sci Technol (2018) 52(21):12819-28. doi: 10.1021/ acs.est.8b04180 JEs, technology.

75. Liebezeit G, Liebezeit E. Synthetic Particles as Contaminants in German Beers. Food Addit Contam Part A (2014) 31(9):1574-8. doi: 10.1080/19440049. 2014.945099

76. Liebezeit G, Liebezeit E. Non-Pollen Particulates in Honey and Sugar. Food Additi Contam Part A (2013) 30(12):2136-40. doi: 10.1080/19440049. 2013.843025

77. Mühlschlegel P, Hauk A, Walter U, Sieber R. Lack of Evidence for Microplastic Contamination in Honey. Food Addit Contam Part A (2017) 34(11):1982-9. doi: 10.1080/19440049.2017.1347281

78. Karami A, Golieskardi A, Choo CK, Larat V, Karbalaei S, Salamatinia B Microplastic and Mesoplastic Contamination in Canned Sardines and Sprats. Sci Total Environ (2018) 612:1380-6. doi: 10.1016/j.scitotenv. 2017.09.005

79. Li Q, Feng Z, Zhang T, Ma C, Shi H. Microplastics in the Commercial Seaweed Nori. J Hazard Mater (2020) 388:122060. doi: 10.1016/ j.jhazmat.2020.122060

80. Hernandez LM, Xu EG, Larsson HC, Tahara R, Maisuria VB, Tufenkji N. Plastic Teabags Release Billions of Microparticles and Nanoparticles Into Tea. Environ Sci Technol (2019) 53(21):12300-10. doi: 10.1021/acs. est.9b02540

81. Rochman CM, Tahir A, Williams SL, Baxa DV, Lam R, Miller JT, et al. Anthropogenic Debris in Seafood: Plastic Debris and Fibers From Textiles in Fish and Bivalves Sold for Human Consumption. Sci Rep (2015) 5(1):1-10. doi: 10.1038/srep14340

82. Van Cauwenberghe L, Janssen CR. Microplastics in Bivalves Cultured for Human Consumption. Environ Pollut (2014) 193:65-70. doi: 10.1016/ j.envpol.2014.06.010 
83. Li J, Yang D, Li L, Jabeen K, Shi H. Microplastics in Commercial Bivalves From China. Environ Pollut (2015) 207:190-5. doi: 10.1016/ j.envpol.2015.09.018

84. Renzi M, Guerranti C, Blašković A. Microplastic Contents From Maricultured and Natural Mussels. Mari Pollut Bull (2018) 131:248-51. doi: 10.1016/j.marpolbul.2018.04.035

85. Abbasi S, Soltani N, Keshavarzi B, Moore F, Turner A, Hassanaghaei M. Microplastics in Different Tissues of Fish and Prawn From the Musa Estuary, Persian Gulf. Chemosphere (2018) 205:80-7. doi: 10.1016/ j.chemosphere.2018.04.076

86. Naji A, Nuri M, Vethaak AD. Microplastics Contamination in Molluscs From the Northern Part of the Persian Gulf. Environ Pollut (2018) 235:11320. doi: 10.1016/j.envpol.2017.12.046

87. Li Q, Sun C, Wang Y, Cai H, Li L, Li J, et al. Fusion of Microplastics Into the Mussel Byssus. Environ Pollut (2019) 252:420-6. doi: 10.1016/j. envpol.2019.05.093

88. Li J, Green C, Reynolds A, Shi H, Rotchell JM. Microplastics in Mussels Sampled From Coastal Waters and Supermarkets in the United Kingdom. Environ Pollut (2018) 241:35-44. doi: 10.1016/j.envpol.2018.05.038

89. Cho Y, Shim WJ, Jang M, Han GM, Hong SH. Abundance and Characteristics of Microplastics in Market Bivalves From South Korea. Environ Pollut (2019) 245:1107-16. doi: 10.1016/j.envpol.2018.11.091

90. De Witte B, Devriese L, Bekaert K, Hoffman S, Vandermeersch G, Cooreman $\mathrm{K}$, et al. Quality Assessment of the Blue Mussel (Mytilus Edulis): Comparison Between Commercial and Wild Types. Mari Pollut Bull (2014) 85(1):146-55. doi: 10.1016/j.marpolbul.2014.06.006

91. Fang C, Zheng R, Chen H, Hong F, Lin L, Lin H, et al. Comparison of Microplastic Contamination in Fish and Bivalves From Two Major Cities in Fujian Province, China and the Implications for Human Health. Aquac (2019) 512:734322. doi: 10.1016/j.aquaculture.2019.734322

92. Baalkhuyur FM, Dohaish E-JAB, Elhalwagy ME, Alikunhi NM, AlSuwailem AM, Røstad A, et al. Microplastic in the Gastrointestinal Tract of Fishes Along the Saudi Arabian Red Sea Coast. Mari Pollut Bull (2018) 131:407-15. doi: 10.1016/j.marpolbul.2018.04.040

93. Akhbarizadeh R, Moore F, Keshavarzi B. Investigating a Probable Relationship Between Microplastics and Potentially Toxic Elements in Fish Muscles From Northeast of Persian Gulf. Environ Pollut (2018) 232:154-63. doi: 10.1016/j.envpol.2017.09.028

94. Bessa F, Barría P, Neto JM, Frias JP, Otero V, Sobral P, et al. Occurrence of Microplastics in Commercial Fish From a Natural Estuarine Environment. Mari Pollut Bull (2018) 128:575-84. doi: 10.1016/j.marpolbul.2018.01.044

95. Collard F, Gilbert B, Compère P, Eppe G, Das K, Jauniaux T, et al. Microplastics in Livers of European Anchovies (Engraulis Encrasicolus, L.). Environ Pollut (2017) 229:1000-5. doi: 10.1016/j.envpol.2017.07.089

96. Compa M, Ventero A, Iglesias M, Deudero S. Ingestion of Microplastics and Natural Fibres in Sardina Pilchardus (Walbaum, 1792) and Engraulis Encrasicolus (Linnaeus, 1758) Along the Spanish Mediterranean Coast. Mari Pollut Bull (2018) 128:89-96. doi: 10.1016/j.marpolbul.2018.01.009

97. Tanaka K, Takada H. Microplastic Fragments and Microbeads in Digestive Tracts of Planktivorous Fish From Urban Coastal Waters. Sci Rep (2016) 6 (1):1-8. doi: 10.1038/srep34351

98. Ferreira P, Fonte E, Soares ME, Carvalho F, Guilhermino L. Effects of MultiStressors on Juveniles of the Marine Fish Pomatoschistus Microps: Gold Nanoparticles, Microplastics and Temperature. Aquat Toxicol (2016) 170:89-103. doi: 10.1016/j.aquatox.2015.11.011

99. Bellas J, Martínez-Armental J, Martínez-Cámara A, Besada V, MartínezGómez C. Ingestion of Microplastics by Demersal Fish From the Spanish Atlantic and Mediterranean Coasts. Mari Pollut Bull (2016) 109(1):55-60. doi: 10.1016/j.marpolbul.2016.06.026

100. Sulochanan B, Bhat G, Lavanya S, Dineshbabu A, Kaladharan P. A Preliminary Assessment of Ecosystem Process and Marine Litter in the Beaches of Mangalore. Ind J Geo Mar Sci (2014) 49(09):1764-9.

101. Zhang F, Wang X, Xu J, Zhu L, Peng G, Xu P, et al. Food-Web Transfer of Microplastics Between Wild Caught Fish and Crustaceans in East China Sea. Mari Pollut Bull (2019) 146:173-82. doi: 10.1016/j.marpolbul.2019.05.061

102. Zhu L, Wang H, Chen B, Sun X, Qu K, Xia B. Microplastic Ingestion in Deep-Sea Fish From the South China Sea. Sci Total Environ (2019) 677:493501. doi: 10.1016/j.scitotenv.2019.04.380
103. Abadi ZTR, Abtahi B, Grossart H-P, Khodabandeh S. Microplastic Content of Kutum Fish, Rutilus Frisii Kutum in the Southern Caspian Sea. Sci Total Environ (2021) 752:141542. doi: 10.1016/j.scitotenv.2020.141542

104. Digka N, Tsangaris C, Torre M, Anastasopoulou A, Zeri C. Microplastics in Mussels and Fish From the Northern Ionian Sea. Mari Pollut Bull (2018) 135:30-40. doi: 10.1016/j.marpolbul.2018.06.063

105. Ghosh GC, Akter SM, Islam RM, Habib A, Chakraborty TK, Zaman S, et al. Microplastics Contamination in Commercial Marine Fish From the Bay of Bengal. Reg Stud Mar Sci (2021) 44:101728. doi: 10.1016/j.rsma.2021.101728

106. Zakeri M, Naji A, Akbarzadeh A, Uddin S. Microplastic Ingestion in Important Commercial Fish in the Southern Caspian Sea. Mari Pollut Bull (2020) 160:111598. doi: 10.1016/j.marpolbul.2020.111598

107. Schwabl P, Köppel S, Königshofer P, Bucsics T, Trauner M, Reiberger T, et al. Detection of Various Microplastics in Human Stool: A Prospective Case Series. Ann Intern Med (2019) 171(7):453-7. doi: 10.7326/M19-0618

108. Amato-Lourenço LF, Carvalho-Oliveira R, Júnior GR, dos Santos Galvão L, Ando RA, Mauad T. Presence of Airborne Microplastics in Human Lung Tissue. J Hazard Mater (2021) 416:126124. doi: 10.1016/j.jhazmat. 2021.126124

109. Mohamed Nor NH, Kooi M, Diepens NJ, Koelmans AA. Lifetime Accumulation of Microplastic in Children and Adults. Environ Sci Ttechnol (2021) 55(8):5084-96. doi: 10.1021/acs.est.0c07384

110. Wang Y, Huang J, Zhu F, Zhou S. Airborne Microplastics: A Review on the Occurrence, Migration and Risks to Humans. Bull Environ Contam Toxicol (2021) 1-8. doi: 10.1007/s00128-021-03180-0

111. Dehghani S, Moore F, Akhbarizadeh R. Microplastic Pollution in Deposited Urban Dust, Tehran Metropolis, Iran. Environl Sci Pollut Res (2017) 24 (25):20360-71. doi: 10.1007/s11356-017-9674-1

112. Yukioka S, Tanaka S, Nabetani Y, Suzuki Y, Ushijima T, Fujii S, et al. Occurrence and Characteristics of Microplastics in Surface Road Dust in Kusatsu (Japan), Da Nang (Vietnam), and Kathmandu (Nepal). Environ Pollut (2020) 256:113447. doi: 10.1016/j.envpol.2019.113447

113. Wright S, Ulke J, Font A, Chan K, Kelly F. Atmospheric Microplastic Deposition in an Urban Environment and an Evaluation of Transport. Environ Int (2020) 136:105411. doi: 10.1016/j.envint.2019.105411

114. Prata JC, da Costa JP, Lopes I, Duarte AC, Rocha-Santos T. Environmental Exposure to Microplastics: An Overview on Possible Human Health Effects. Sci Total Environ (2020) 702:134455. doi: 10.1016/j.scitotenv.2019.134455

115. Pauly JL, Stegmeier SJ, Allaart HA, Cheney RT, Zhang PJ, Mayer AG, et al. Inhaled Cellulosic and Plastic Fibers Found in Human Lung Tissue. Cancer Epidemiol Prev Biomarkers (1998) 7(5):419-28.

116. Gasperi J, Wright SL, Dris R, Collard F, Mandin C, Guerrouache M, et al. Microplastics in Air: Are We Breathing It in? Curr Opin J Environ Sci Health (2018) 1:1-5. doi: 10.1016/j.coesh.2017.10.002

117. Vethaak AD, Leslie HA. Plastic Debris Is a Human Health Issue. Environ Sci Technol (2016) 50(13):6825-6. doi: 10.1021/acs.est.6b02569

118. Donaldson K, Stone V, Gilmour P, Brown D, MacNee W. Ultrafine Particles: Mechanisms of Lung Injury. Philos Trans R Soc London Ser A Math Phys Eng Sci (2000) 358(1775):2741-9. doi: 10.1098/rsta.2000.0681

119. Turcotte SE, Chee A, Walsh R, Grant FC, Liss GM, Boag A, et al. Flock Worker's Lung Disease: Natural History of Cases and Exposed Workers in Kingston, Ontario. Chest (2013) 143(6):1642-8. doi: 10.1378/chest.12-0920

120. Koelmans AA, Nor NHM, Hermsen E, Kooi M, Mintenig SM, De France J. Microplastics in Freshwaters and Drinking Water: Critical Review and Assessment of Data Quality. Water Res (2019) 155:410-22. doi: 10.1016/ j.watres.2019.02.054

121. Zhang Q, Xu EG, Li J, Chen Q, Ma L, Zeng EY, et al. A Review of Microplastics in Table Salt, Drinking Water, and Air: Direct Human Exposure. Environ Sci Technol (2020) 54(7):3740-51. doi: 10.1021/ acs.est.9b04535

122. Shruti V, Pérez-Guevara F, Elizalde-Martínez I, Kutralam-Muniasamy G. Toward a Unified Framework for Investigating Micro (Nano) Plastics in Packaged Beverages Intended for Human Consumption. Environ Pollut (2020) 268:115811. doi: 10.1016/j.envpol.2020.115811

123. Elizalde-Velázquez GA, Gómez-Oliván LM. Microplastics in Aquatic Environments: A Review on Occurrence, Distribution, Toxic Effects, and Implications for Human Health. Sci Total Environ (2021) 780:146551. doi: 10.1016/j.scitotenv.2021.146551 
124. LI WC, Tse H, Fok L. Plastic Waste in the Marine Environment: A Review of Sources, Occurrence and Effects. Sci Total Environ (2016) 566:333-49. doi: 10.1016/j.scitotenv.2016.05.084

125. Mathalon A, Hill P. Microplastic Fibers in the Intertidal Ecosystem Surrounding Halifax Harbor, Nova Scotia. Mari Pollut Bull (2014) 81 (1):69-79. doi: 10.1016/j.marpolbul.2014.02.018

126. Neves D, Sobral P, Ferreira JL, Pereira T. Ingestion of Microplastics by Commercial Fish Off the Portuguese Coast. Mari Pollut Bull (2015) 101 (1):119-26. doi: 10.1016/j.marpolbul.2015.11.008

127. Chain EPoCitF. Presence of Microplastics and Nanoplastics in Food, With Particular Focus on Seafood. Efsa Jl (2016) 14(6):e04501. doi: 10.2903/ j.efsa.2016.4501

128. Fournier E, Etienne-Mesmin L, Grootaert C, Jelsbak L, Syberg K, BlanquetDiot S, et al. Microplastics in the Human Digestive Environment: A Focus on the Potential and Challenges Facing In Vitro Gut Model Development. J Hazard Mater (2021) 415:125632. doi: 10.1016/j.jhazmat.2021.125632

129. Zarus GM, Muianga C, Hunter C, Pappas RS. A Review of Data for Quantifying Human Exposures to Micro and Nanoplastics and Potential Health Risks. Sci Total Environ (2020) 756:144010. doi: 10.1016/ j.scitotenv.2020.144010

130. Lwanga EH, Vega JM, Quej VK, de los Angeles Chi J, Del Cid LS, Chi C, et al. Field Evidence for Transfer of Plastic Debris Along a Terrestrial Food Chain. Sci Rep (2017) 7(1):1-7. doi: 10.1038/s41598-017-14588-2

131. Li D, Shi Y, Yang L, Xiao L, Kehoe DK, Gun'ko YK, et al. Microplastic Release From the Degradation of Polypropylene Feeding Bottles During Infant Formula Preparation. Nat Food (2020) 1(11):746-54. doi: 10.1038/ s43016-020-00171-y

132. Yang D, Shi H, Li L, Li J, Jabeen K, Kolandhasamy P. Microplastic Pollution in Table Salts From China. Environ Sci Technol (2015) 49(22):13622-7. doi: 10.1021/acs.est.5b03163

133. Bouwmeester H, Hollman PC, Peters RJ. Potential Health Impact of Environmentally Released Micro-and Nanoplastics in the Human Food Production Chain: Experiences From Nanotoxicology. Environ Sci Technol (2015) 49(15):8932-47. doi: 10.1021/acs.est.5b01090

134. Kedzierski M, Lechat B, Sire O, Le Maguer G, Le Tilly V, Bruzaud S. Microplastic Contamination of Packaged Meat: Occurrence and Associated Risks. Food Packag Shelf Life (2020) 24:100489. doi: 10.1016/j.fpsl. 2020.100489

135. Kutralam-Muniasamy G, Pérez-Guevara F, Elizalde-Martínez I, Shruti V. Branded Milks-Are They Immune From Microplastics Contamination? Sci Total Environ (2020) 714:136823. doi: 10.1016/j.scitotenv.2020.136823

136. Yadav K. Diagnosis of the Failure of Ultrafiltration Membranes Used in the Dairy Industry. (2009). doi: 10.26021/2630

137. Watts AJ, Lewis C, Goodhead RM, Beckett SJ, Moger J, Tyler CR, et al. Uptake and Retention of Microplastics by the Shore Crab Carcinus Maenas. Environ Sci Technol (2014) 48(15):8823-30. doi: 10.1021/es501090e

138. Toussaint B, Raffael B, Angers-Loustau A, Gilliland D, Kestens V, Petrillo M, et al. Review of Micro-and Nanoplastic Contamination in the Food Chain. Food Addit Contam Part A (2019) 36(5):639-73. doi: 10.1080/19440049. 2019.158338

139. Cheung PK, Fok L. Evidence of Microbeads From Personal Care Product Contaminating the Sea. Mari Pollut Bull (2016) 109(1):582-5. doi: 10.1016/ j.marpolbul.2016.05.046

140. Borrero-Lopez O, Guiberteau F, Zhang Y, Lawn BR. Wear of Ceramic-Based Dental Materials. J Mechl Behav Biomedl Mater (2019) 92:144-51. doi: 10.1016/j.jmbbm.2019.01.009

141. Gouin T, Avalos J, Brunning I, Brzuska K, De Graaf J, Kaumanns J, et al. Use of Micro-Plastic Beads in Cosmetic Products in Europe and Their Estimated Emissions to the North Sea Environment. SOFW J (2015) 141 (4):40-6.

142. Habib RZ, Abdoon MMS, Al Meqbaali RM, Ghebremedhin F, Elkashlan M, Kittaneh WF, et al. Analysis of Microbeads in Cosmetic Products in the United Arab Emirates. Environ Pollut (2020) 258:113831. doi: 10.1016/ j.envpol.2019.113831

143. Gouin T, Roche N, Lohmann R, Hodges G. A Thermodynamic Approach for Assessing the Environmental Exposure of Chemicals Absorbed to Microplastic. Environ Sci Technol (2011) 45(4):1466-72. doi: 10.1021/es1032025
144. Napper IE, Bakir A, Rowland SJ, Thompson RC. Characterisation, Quantity and Sorptive Properties of Microplastics Extracted From Cosmetics. Mari Pollut Bull (2015) 99(1-2):178-85. doi: 10.1016/j.marpolbul.2015.07.029

145. Anagnosti L, Varvaresou A, Pavlou P, Protopapa E, Carayanni V. Worldwide Actions Against Plastic Pollution From Microbeads and Microplastics in Cosmetics Focusing on European Policies. Has the Issue Been Handled Effectively? Mari Pollut Bull (2021) 162:111883. doi: 10.1016/j. marpolbul.2020.111883

146. Rahman A, Sarkar A, Yadav OP, Achari G, Slobodnik J. Potential Human Health Risks Due to Environmental Exposure to Microplastics and Knowledge Gaps: A Scoping Review. Sci Total Environ (2020) 757:143872. doi: $10.1016 /$ j.scitotenv.2020.143872

147. Xu C, Zhang B, Gu C, Shen C, Yin S, Aamir M, et al. Are We Underestimating the Sources of Microplastic Pollution in Terrestrial Environment? J Hazard Mater (2020) 400:123228. doi: 10.1016/ j.jhazmat.2020.123228

148. Sillanpää M, Sainio P. Release of Polyester and Cotton Fibers From Textiles in Machine Washings. Environ Sci Pollut Res (2017) 24(23):19313-21. doi: 10.1007/s11356-017-9621-1

149. Suhrhoff TJ, Scholz-Böttcher BM. Qualitative Impact of Salinity, UV Radiation and Turbulence on Leaching of Organic Plastic Additives From Four Common Plastics-A Lab Experiment. Mari Pollut Bull (2016) 102 (1):84-94. doi: 10.1016/j.marpolbul.2015.11.054

150. Hermabessiere L, Dehaut A, Paul-Pont I, Lacroix C, Jezequel R, Soudant P, et al. Occurrence and Effects of Plastic Additives on Marine Environments and Organisms: A Review. Chemosphere (2017) 182:781-93. doi: 10.1016/ j.chemosphere.2017.05.096

151. Wiesinger H, Wang Z, Hellweg S. Deep Dive Into Plastic Monomers, Additives, and Processing Aids. Environ Sci Technol (2021) 55(13):933951. doi: 10.1021/acs.est.1c00976

152. Rani M, Shim WJ, Han GM, Jang M, Al-Odaini NA, Song YK, et al. Qualitative Analysis of Additives in Plastic Marine Debris and Its New Products. Arch Environ Con Toxicol (2015) 69(3):352-66. doi: 10.1007/ s00244-015-0224-x

153. Chen D, Kannan K, Tan H, Zheng Z, Feng Y-L, Wu Y, et al. Bisphenol Analogues Other Than BPA: Environmental Occurrence, Human Exposure, and Toxicity a Review. Environ Sci Technol (2016) 50(11):5438-53. doi: $10.1021 /$ acs.est.5b05387

154. Engler RE. The Complex Interaction Between Marine Debris and Toxic Chemicals in the Ocean. Environl Sci Technol (2012) 46(22):12302-15. doi: 10.1021/es3027105

155. Lau O-W, Wong S-K. Contamination in Food From Packaging Material. J Chromatogr A (2000) 882(1-2):255-70. doi: 10.1016/S0021-9673(00) 00356-3

156. Wang J, Cheng J, Liu J, Gao Y, Sun F. Self-Floating Ability and Initiating Gradient Photopolymerization of Acrylamide Aqueous Solution of a WaterSoluble Polysiloxane Benzophenone Photoinitiator. Green Chem (2013) 15 (9):2457-65. doi: 10.1039/C3GC40704G

157. Liao C, Kim U-J, Kannan K. A Review of Environmental Occurrence, Fate, Exposure, and Toxicity of Benzothiazoles. Environ Sci Technol (2018) 52 (9):5007-26. doi: 10.1021/acs.est.7b05493

158. Kannan K, Takahashi S, Fujiwara N, Mizukawa H, Tanabe S. Organotin Compounds, Including Butyltins and Octyltins, in House Dust From Albany, New York, USA. Arch Environ Con Toxicol (2010) 58(4):901-7. doi: 10.1007/ s00244-010-9513-6

159. Guo Y, Kannan K. A Survey of Phthalates and Parabens in Personal Care Products From the United States and Its Implications for Human Exposure. Environ Sci Technol (2013) 47(24):14442-9. doi: 10.1021/es4042034

160. Wang Y, Zhu H, Kannan K. A Review of Biomonitoring of Phthalate Exposures. Toxics (2019) 7(2):21. doi: 10.3390/toxics7020021

161. Liao C, Kannan K. A Survey of Alkylphenols, Bisphenols, and Triclosan in Personal Care Products From China and the United States. Arch Environ Con Toxicol (2014) 67(1):50-9. doi: 10.1007/s00244-014-0016-8

162. Asimakopoulos AG, Wang L, Thomaidis NS, Kannan K. Benzotriazoles and Benzothiazoles in Human Urine From Several Countries: A Perspective on Occurrence, Biotransformation, and Human Exposure. Environ Int (2013) 59:274-81. doi: 10.1016/j.envint.2013.06.007 
163. Johnson-Restrepo B, Kannan K. An Assessment of Sources and Pathways of Human Exposure to Polybrominated Diphenyl Ethers in the United States. Chemosphere (2009) 76(4):542-8. doi: 10.1016/j.chemosphere.2009.02.068

164. Volkheimer G. Hematogenous Dissemination of Ingested Polyvinyl Chloride Particles. Ann NY Acad Sci (1975) 246:164-71. doi: 10.1111/j.17496632.1975.tb51092.x

165. Walczak AP, Kramer E, Hendriksen PJ, Tromp P, Helsper JP, van der Zande M, et al. Translocation of Differently Sized and Charged Polystyrene Nanoparticles in In Vitro Intestinal Cell Models of Increasing Complexity. Nanotoxicology (2015) 9(4):453-61. doi: 10.3109/17435390.2014.944599

166. Luo T, Zhang Y, Wang C, Wang X, Zhou J, Shen M, et al. Maternal Exposure to Different Sizes of Polystyrene Microplastics During Gestation Causes Metabolic Disorders in Their Offspring. Environ Pollut (2019) 255:113122. doi: 10.1016/j.envpol.2019.113122

167. Banerjee A, Shelver WL. Micro-And Nanoplastic Induced Cellular Toxicity in Mammals: A Review. Sci Total Environ (2020) 755:142518. doi: 10.1016/ j.scitotenv.2020.142518

168. Smith M, Love DC, Rochman CM, Neff RA. Microplastics in Seafood and the Implications for Human Health. Curr Environ Health Rep (2018) 5(3):37586. doi: 10.1007/s40572-018-0206-Z

169. Eldridge JH, Meulbroek JA, Staas JK, Tice TR, Gilley RM. VaccineContaining Biodegradable Microspheres Specifically Enter the GutAssociated Lymphoid Tissue Following Oral Administration and Induce a Disseminated Mucosal Immune Response. Immunobiol Proteins Peptides $V$ Springer (1989) 191-202. doi: 10.1007/978-1-4757-2046-4_18

170. Shelver W, Banerjee A. Micro/nanoplastic Mediated Pathophysiological Changes in Rodents, Rabbits, and Chicken. J Food Prot (2021) 84(9):148095. doi: $10.4315 / \mathrm{jfp}-21-117$

171. Prietl B, Meindl C, Roblegg E, Pieber T, Lanzer G, Fröhlich E. Nano-Sized and Micro-Sized Polystyrene Particles Affect Phagocyte Function. Cell Biol Toxicol (2014) 30(1):1-16. doi: 10.1007/s10565-013-9265-y

172. Wick P, Malek A, Manser P, Meili D, Maeder-Althaus X, Diener L, et al. Barrier Capacity of Human Placenta for Nanosized Materials. Environ Health Perspect (2010) 118(3):432-6. doi: 10.1289/ehp.0901200

173. Millburn P, Smith R, Williams R. Biliary Excretion of Foreign Compounds. Biphenyl, Stilboestrol and Phenolphthalein in the Rat: Molecular Weight, Polarity and Metabolism as Factors in Biliary Excretion. Biochem (1967) 105 (3):1275-81. doi: 10.1042/bj1051275

174. Yang B, Lee C, Xiang W, Xie J, He JH, Kotlanka RK, et al. Electromagnetic Energy Harvesting From Vibrations of Multiple Frequencies. J Micromech Microeng (2009) 19(3):35001. doi: 10.1088/0960-1317/19/3/035001

175. Urban RM, Jacobs JJ, Tomlinson MJ, Gavrilovic J, Black J, Peoc'h M. Dissemination of Wear Particles to the Liver, Spleen, and Abdominal Lymph Nodes of Patients With Hip or Knee Replacement. JBJS (2000) 82 (4):457. doi: 10.2106/00004623-200004000-00002

176. Ibrahim YS, Tuan Anuar S, Azmi AA, Wan Mohd Khalik WMA, Lehata S, Hamzah SR, et al. Detection of Microplastics in Human Colectomy Specimens. JGH Open (2021) 5(1):116-21. doi: 10.1002/jgh3.12457

177. Schirinzi GF, Pérez-Pomeda I, Sanchís J, Rossini C, Farré M, Barceló D. Cytotoxic Effects of Commonly Used Nanomaterials and Microplastics on Cerebral and Epithelial Human Cells. Environ Res (2017) 159:579-87. doi: 10.1016/j.envres.2017.08.043

178. Wu B, Wu X, Liu S, Wang Z, Chen L. Size-Dependent Effects of Polystyrene Microplastics on Cytotoxicity and Efflux Pump Inhibition in Human Caco-2 Cells. Chemosphere (2019) 221:333-41. doi: 10.1016/j.chemosphere. 2019.01.056

179. Wu S, Wu M, Tian D, Qiu L, Li T. Effects of Polystyrene Microbeads on Cytotoxicity and Transcriptomic Profiles in Human Caco-2 Cells. Environ Toxicol (2020) 35(4):495-506. doi: 10.1002/tox.22885

180. Lehner R, Wohlleben W, Septiadi D, Landsiedel R, Petri-Fink A, RothenRutishauser B. A Novel 3D Intestine Barrier Model to Study the Immune Response Upon Exposure to Microplastics. Arch Toxicol (2020) 94(7):246379. doi: 10.1007/s00204-020-02750-1

181. Deng Y, Zhang Y, Lemos B, Ren H. Tissue Accumulation of Microplastics in Mice and Biomarker Responses Suggest Widespread Health Risks of Exposure. Sci Rep (2017) 7(1):1-10. doi: 10.1038/srep46687

182. Lu L, Wan Z, Luo T, Fu Z, Jin Y. Polystyrene Microplastics Induce Gut Microbiota Dysbiosis and Hepatic Lipid Metabolism Disorder in
Mice. Sci Total Environ (2018) 631:449-58. doi: 10.1016/j.scitotenv.2018. 03.051

183. Deng Y, Zhang Y, Qiao R, Bonilla MM, Yang X, Ren H, et al. Evidence That Microplastics Aggravate the Toxicity of Organophosphorus Flame Retardants in Mice (Mus Musculus). J Hazard Mater (2018) 357:348-54. doi: 10.1016/j.jhazmat.2018.06.017

184. Jin Y, Lu L, Tu W, Luo T, Fu Z. Impacts of Polystyrene Microplastic on the Gut Barrier, Microbiota and Metabolism of Mice. Sci Total Environ (2019) 649:308-17. doi: 10.1016/j.scitotenv.2018.08.353

185. Yang Y-F, Chen C-Y, Lu T-H, Liao C-M. Toxicity-Based Toxicokinetic/ Toxicodynamic Assessment for Bioaccumulation of Polystyrene Microplastics in Mice. J Hazard Mater (2019) 366:703-13. doi: 10.1016/ j.jhazmat.2018.12.048

186. Luo T, Wang C, Pan Z, Jin C, Fu Z, Jin Y. Maternal Polystyrene Microplastic Exposure During Gestation and Lactation Altered Metabolic Homeostasis in the Dams and Their F1 and F2 Offspring. Environ Sci Technol (2019) 53 (18):10978-92. doi: 10.1021/acs.est.9b03191

187. Li B, Ding Y, Cheng X, Sheng D, Xu Z, Rong Q, et al. Polyethylene Microplastics Affect the Distribution of Gut Microbiota and Inflammation Development in Mice. Chemosphere (2020) 244:125492. doi: 10.1016/ j.chemosphere.2019.125492

188. Baillie-Hamilton PF. Chemical Toxins: A Hypothesis to Explain the Global Obesity Epidemic. J Altern Complement Med (2002) 8(2):185-92. doi: $10.1089 / 107555302317371479$

189. Newbold RR, Padilla-Banks E, Jefferson WN. Environmental Estrogens and Obesity. Mol Cell Endocrinol (2009) 304(1-2):84-9. doi: 10.1016/ j.mce.2009.02.024

190. Brown RE, Sharma AM, Ardern CI, Mirdamadi P, Mirdamadi P, Kuk JL. Secular Differences in the Association Between Caloric Intake, Macronutrient Intake, and Physical Activity With Obesity. Obes Res Clin Pract (2016) 10(3):243-55. doi: 10.1016/j.orcp.2015.08.007

191. Egusquiza RJ, Blumberg B. Environmental Obesogens and Their Impact on Susceptibility to Obesity: New Mechanisms and Chemicals. Endocrinology (2020) 161(3):bqaa024. doi: 10.1210/endocr/bqaa024

192. Heindel JJ, Blumberg B. Environmental Obesogens: Mechanisms and Controversies. Annu Rev Pharmacol Toxicol (2019) 59:89-106. doi: 10.1146/annurev-pharmtox-010818-021304

193. Goodman JM. The Importance of Microlipophagy in Liver. Proc Natl Acad Sci (2021) 118(2). doi: 10.1073/pnas.2024058118

194. Plata C, Cruz C, Cervantes LG, Ramírez V. The Gut Microbiota and Its Relationship With Chronic Kidney Disease. Int Urol Nephrol (2019) 51 (12):2209-26. doi: 10.1007/s11255-019-02291-2

195. Jin M, Qian Z, Yin J, Xu W, Zhou X. The Role of Intestinal Microbiota in Cardiovascular Disease. J Cell Mol Med (2019) 23(4):2343-50. doi: 10.1111/ jcmm.14195

196. Francescone R, Hou V, Grivennikov SI. Microbiome, Inflammation and Cancer. Cancer J (Sudbury Mass) (2014) 20(3):181. doi: 10.1097/ PPO.0000000000000048

197. Ma Q, Xing C, Long W, Wang HY, Liu Q, Wang R-F. Impact of Microbiota on Central Nervous System and Neurological Diseases: The Gut-Brain Axis. J Neuroinflamm (2019) 16(1):1-14. doi: 10.1186/s12974-019-1434-3

198. Chamorro-Garcia R, Blumberg B. Current Research Approaches and Challenges in the Obesogen Field. Front Endocrinol (2019) 10:2019.00167. doi: 10.3389/fendo.2019.00167

199. Grun F, Watanabe H, Zamanian Z, Maeda L, Arima K, Cubacha R, et al. Endocrine-Disrupting Organotin Compounds Are Potent Inducers of Adipogenesis in Vertebrates. J Mol Endocrinol (2006) 20(9):2141-55. doi: 10.1210/me.2005-0367

200. Manikkam M, Tracey R, Guerrero-Bosagna C, Skinner MK. Plastics Derived Endocrine Disruptors (BPA, DEHP and DBP) Induce Epigenetic Transgenerational Inheritance of Obesity, Reproductive Disease and Sperm Epimutations. PloS One (2013) 8(1):e55387. doi: 10.1371/ journal.pone. 0055387

201. Vom Saal FS, Nagel SC, Coe BL, Angle BM, Taylor JA. The Estrogenic Endocrine Disrupting Chemical Bisphenol A (BPA) and Obesity. Mol Cell Endocrinol (2012) 354(1-2):74-84. doi: 10.1016/j.mce.2012.01.001

202. Hirata-Koizumi M, Ise R, Kato H, Matsuyama T, Nishimaki-Mogami T, Takahashi M, et al. Transcriptome Analyses Demonstrate That Peroxisome 
Proliferator-Activated Receptor $\alpha$ (Ppar $\alpha)$ Activity of an Ultraviolet Absorber, 2-(2'-Hydroxy-3', 5'-Di-Tert-Butylphenyl) Benzotriazole, as Possible Mechanism of Their Toxicity and the Gender Differences. J Toxicol Sci (2016) 41(5):693-700. doi: 10.2131/jts.41.693

203. Cantón RF, Peijnenburg AA, Hoogenboom RL, Piersma AH, van der Ven LT, van den Berg M, et al. Subacute Effects of Hexabromocyclododecane (HBCD) on Hepatic Gene Expression Profiles in Rats. Toxicol Appl Pharmacol (2008) 231(2):267-72. doi: 10.1016/j.taap.2008.04.013

204. Nguyen HT, Li L, Eguchi A, Kannan K, Kim E-Y, Iwata H. Effects on the Liver Lipidome of Rat Offspring Prenatally Exposed to Bisphenol A. Sci Total Environ (2021) 759:143466. doi: 10.1016/j.scitotenv.2020.143466

205. Desvergne B, Feige JN, Casals-Casas C. PPAR-Mediated Activity of Phthalates: A Link to the Obesity Epidemic? Mol Cell Endocrinol (2009) 304(1-2):43-8. doi: 10.1016/j.mce.2009.02.017

206. Janesick AS, Shioda T, Blumberg B. Transgenerational Inheritance of Prenatal Obesogen Exposure. Mol Cell Endocrinol (2014) 398(1-2):31-5. doi: 10.1016/j.mce.2014.09.002

207. Chamorro-García R, Sahu M, Abbey RJ, Laude J, Pham N, Blumberg B. Transgenerational Inheritance of Increased Fat Depot Size, Stem Cell Reprogramming, and Hepatic Steatosis Elicited by Prenatal Exposure to the Obesogen Tributyltin in Mice. Environ Health Perspect (2013) 121 (3):359-66. doi: 10.1289/ehp.1205701
Author Disclaimer: The content is solely the responsibility of the authors and does not necessarily represent the official views of the NIH. The use of trade names does not imply endorsement of the product by the authors or affiliated institution or the funding agency.

Conflict of Interest: The authors declare that the research was conducted in the absence of any commercial or financial relationships that could be construed as a potential conflict of interest.

Publisher's Note: All claims expressed in this article are solely those of the authors and do not necessarily represent those of their affiliated organizations, or those of the publisher, the editors and the reviewers. Any product that may be evaluated in this article, or claim that may be made by its manufacturer, is not guaranteed or endorsed by the publisher.

Copyright (C) 2021 Kannan and Vimalkumar. This is an open-access article distributed under the terms of the Creative Commons Attribution License (CC BY). The use, distribution or reproduction in other forums is permitted, provided the original author(s) and the copyright owner(s) are credited and that the original publication in this journal is cited, in accordance with accepted academic practice. No use, distribution or reproduction is permitted which does not comply with these terms. 